\title{
Biscuits: a systematic review and meta- analysis of improving the nutritional quality and health benefits
}

\author{
Mahamadé Goubgou ${ }^{1,2^{*}}$ (D), Laurencia T. Songré-Ouattara ${ }^{2}$, Fabrice Bationo ${ }^{2}$, Hagrétou Lingani-Sawadogo ${ }^{2}$, \\ Yves Traoré ${ }^{1}$ (1) and Aly Savadogo ${ }^{1}$ (B)
}

\begin{abstract}
Biscuits are ready-to-eat foods that are traditionally prepared mainly with wheat flour, fat, and sugar. Recently, biscuits' technologies have been rapidly developed to improve their nutritional properties. This study aimed to determine the strategies of improving the nutritional quality of biscuits and the potential health benefits associated with them. A systematic review and meta-analysis were conducted, including articles on biscuits improved by technological processes and raw materials variation. Studies were searched from Google Scholar, PubMed, Scopus, and Web of Science published between 1997 and 2020, in English and French. The meta-analysis was performed using RStudio software, version 4.0.4 to classify the biscuits. One hundred and seven eligible articles were identified. Rice, pea, potato, sorghum, buckwheat, and flaxseed flours were respectively the most found substitutes to wheat flour. But the meta-analysis shown that the copra and foxtail millet biscuit fortified with amaranth, the wheat biscuits fortified with okra, and rice biscuits fortified with soybeans had a high protein content. These biscuits therefore have a potential to be used as complementary foods. The substitution of sugar and fat by several substitutes lead to a decrease in carbohydrates, fat, and energy value. It has also brought about an increase in other nutrients such as dietary fiber, proteins/amino acids, fatty acids, and phenolic compounds. Among the sugar and fat substitutes, stevia and inulin were respectively the most used. Regarding the use of biscuits in clinical trials, they were mainly used for addressing micronutrient deficiency and for weight loss.
\end{abstract}

Keywords: Biscuit, Technology, Nutrition, Health benefits

\section{Introduction}

Many efforts have been made to develop food products that can improve people's health (Coutinho de Moura et al. 2014; Galanakis 2020; Granato et al. 2010). In developing countries, while overweight/obesity is increasing in all age groups, undernutrition persists and coexists with obesity and the burden of diet-related diseases (World Health Organization 2021). Furthermore, recent outbreaks of infectious diseases, such as malaria,

\footnotetext{
* Correspondence: m.goubgou2@gmail.com

'Doctoral School of Sciences and Technology, Laboratory of Applied Biochemistry and Immunology (LABIA), University Joseph KI-ZERBO, Ouagadougou, Burkina Faso

2Department of Food Technology (DTA), Research Institute of Applied Sciences and Technology (IRSAT), Ouagadougou, Burkina Faso
}

Ebola virus disease, HIV pandemic, and the recent COVID-19 crisis emphasize the need to adopt healthy diets (Galanakis 2020). As a result, many health organizations have been incentivized to the development and consumption of improved food, such as food enriched with functional constituents (French Ministry of Health 2006; Hercberg et al. 2008; World Health Organization 2015). For this purpose, several popular or traditional foods have been used as vehicles in fortification strategies.

Popular foods are effective vehicles for nutrient incorporation and are thus targeted by a growing and increasingly demanding market for the management of health disorders (Granato et al. 2010). Among these foods, biscuits show potential as improved food (Nogueira \&

(c) The Author(s). 2021 Open Access This article is licensed under a Creative Commons Attribution 4.0 International License, which permits use, sharing, adaptation, distribution and reproduction in any medium or format, as long as you give

appropriate credit to the original author(s) and the source, provide a link to the Creative Commons licence, and indicate if changes were made. The images or other third party material in this article are included in the article's Creative Commons licence, unless indicated otherwise in a credit line to the material. If material is not included in the article's Creative Commons licence and your intended use is not permitted by statutory regulation or exceeds the permitted use, you will need to obtain permission directly from the copyright holder. To view a copy of this licence, visit http://creativecommons.org/licenses/by/4.0/ 
Steel 2018) to meet nutritional needs or prevent dietrelated illnesses. Biscuits offer several possibilities for the management of human nutrition-related disorders. They are widely consumed as snacks or as complement to other foods. They present varied forms and pleasant flavors, have long shelf lives, and provide convenience (AgamaAcevedo et al. 2012; Manley 2011). Therefore, the production and consumption of biscuits have considerably increased worldwide (Canalis et al. 2017). For products with the fast-moving consumer goods category, the biscuit market is among the leading ones (Apeda agri exchange 2020). The biscuit market reached $\$ 76.385$ billion at the end of 2017 and expected to reach USD 121 billion by 2021 and USD 164 billion by 2024 at compound annual growth rate (CAGR) of 3.7 and $5.08 \%$, respectively (Apeda agri exchange 2020). The highest per capita consumption of biscuits in the world is approximately $13 \mathrm{~kg}$ per year (Canalis et al. 2017). The wide consumption of biscuit makes it an ideal product for fortification (Kadam \& Prabhasankar 2010). However, some biscuits are even used as part of nutritional strategies to tackle several chronic and nutrition-related diseases, such as nutrient deficiencies, diabetes, obesity, cardiovascular diseases, and cancers (Canalis et al. 2017; Singh \& Kumar 2017; van Stuijvenberg et al. 2001). Innovations in biscuit technologies and recipes have resulted in a wide range of biscuit products, both the forms and nutritional properties (Denis 2011; Filipčev et al. 2014; Swapna \& Jayaraj Rao 2016). Biscuits have many functional forms and can be enriched with mineral and vitamin complexes (MVC) or nutrient-rich complementary ingredients, and formulated for infants, children, the elderly and those with special needs such as the obese and diabetics (Davidson 2019). The fortification ability of biscuits and their high consumer acceptance have led to them receiving more attention for formulating functional foods or nutraceuticals. Several clinical trials have also been carried out on the efficacy of improved biscuits against illnesses and prevention of chronic and nutrition-related diseases (Kriengsinyos et al. 2015; Kekalih et al. 2019; Buffière et al. 2020). Compared to the large number of biscuits currently available, the number of research studies examining improved biscuits and their use in clinical trials is quite limited. Therefore, this paper reviews the different improved biscuits and their use in clinical trials against illnesses and risk of chronic diseases such as malnutrition, diabetes, hypertension, cardiovascular disease, cancer, obesity, low HDL cholesterol, high triglyceride level, etc.

\section{Methods}

\section{Search strategy}

At first, this study searched in many databases as Google Scholar, PubMed, Scopus, Web of Science with keywords. These keywords are: Biscuit OR Cookie OR Cracker AND
Improved quality, Biscuit OR Cookie OR Cracker AND High quality, Improved Biscuit OR Cookie OR Cracker, High quality Biscuit OR Cookie OR Cracker, Biscuit OR Cookie OR Cracker AND Health benefits, Biscuit OR Cookie OR Cracker AND Clinical trial, Biscuit OR Cookie OR Cracker AND Trial. Secondly, references of all identified articles were searched to get additional studies. Figure 1 shows the articles selection procedure and information used in this study.

\section{Inclusion criteria}

Studies with the following criteria were eligible for inclusion: 1) studies that have investigated the effect of total or partial substitution of wheat flour; 2) studies that have investigated the effect of substitution or the reduction of sugar or fat for the production of biscuits; 3 ) studies that have investigated novelties in the processing of improved biscuits; 4) studies that have investigated the use of improved biscuits in clinical trials.

The term "biscuit" derives from the Latin word biscoctus, which means twice-cooked/baked (Chavan et al. 2016). The origin of biscuit dates back to Roman times to resolve food preservation (Chavan et al. 2016). In baking, the word "biscuit" includes several groups of products. It is called "biscuit" in the United Kingdom and in France, "cookie" and "cracker" in the United States, and "scone" in New Zealand (Chavan et al. 2016; Denis 2011). For other authors, biscuits are termed interchangeably with cookies in the United Kingdom and Asia (Cauvain \& Young 2008). However, some differences can be noted between the products. Biscuits are generally made from short dough, which is undeveloped and lacks extensibility (Xu et al. 2020) while cookies are made from soft dough, which has high sugar, high fat, and low moisture content (Delcour \& Hoseney 2010). Cracker, for instance, is traditionally made from soft dough and is a thin and crisp product baked from unsweetened and unleavened dough (Xu et al. 2020). In this paper, the term biscuit is used for biscuits, cookies, and cracker.

\section{Exclusion criteria}

Letters, comments, communications, reviews, thesis, and animal studies were excluded. Also, excluded were articles published in languages other than English and French, citations with no abstracts and/or full texts, duplicate studies, and articles focusing solely on biscuits ingredients and dough studies. Furthermore, for the quantitative synthesis (meta-analysis), the articles reporting only on physical, sensorial, and rheological properties, clinical trials, and those that did not determine jointly proteins, fats, ashes, carbohydrates, and fibers contents were excluded. 


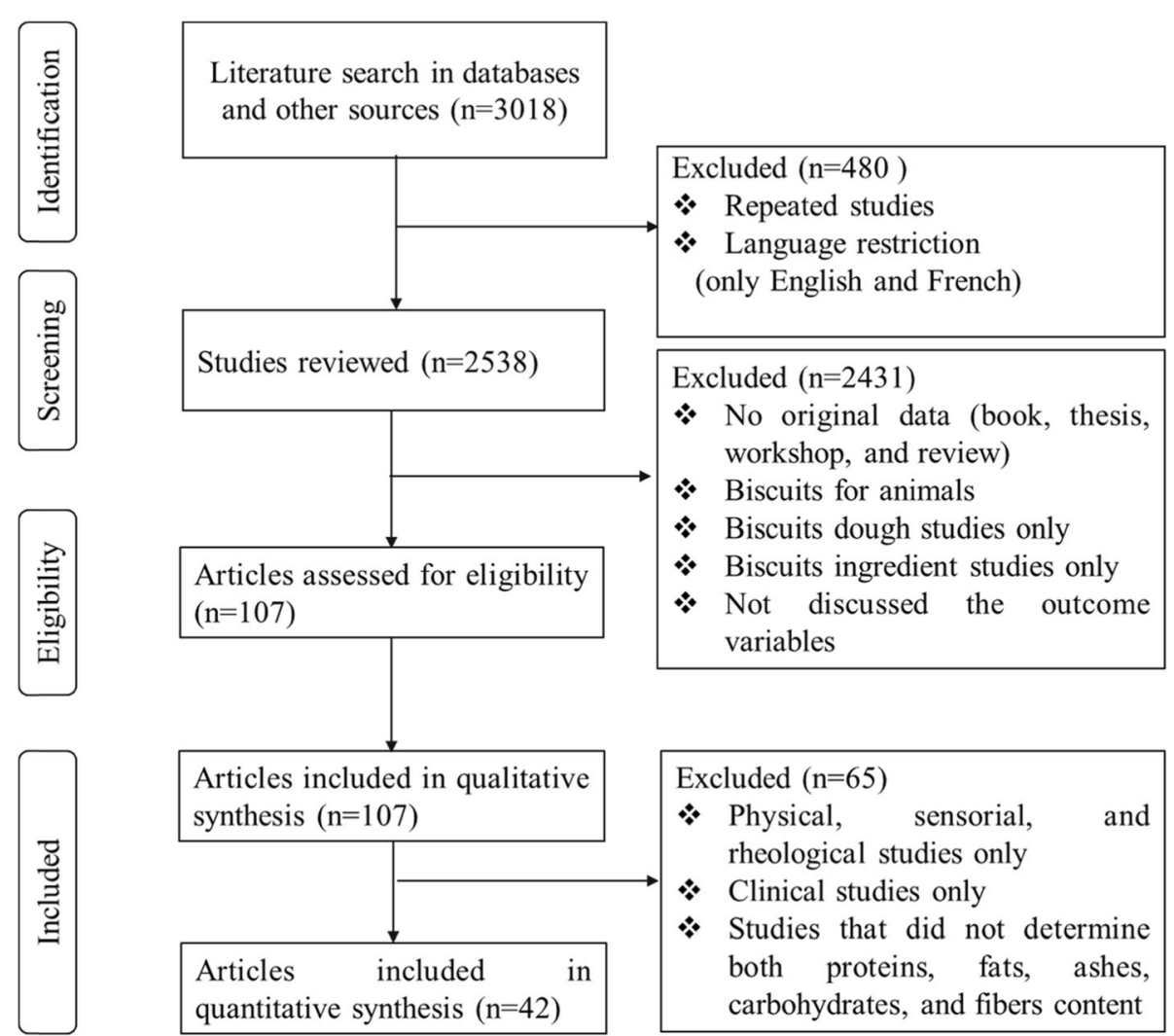

Fig. 1 Flow chart of screening process

\section{Synthesis of findings}

The included articles were analysed qualitatively using a thematic analysis approach. Then, all articles were synthesized by systematic reading.

\section{Results}

\section{Study characteristics}

In our initial search, we found 3018 articles, of which 480 were identified as repeated studies or language restriction (only English and French) and were excluded. After reviewing titles and abstracts, 2431 articles were also excluded for the following reasons: 1) no original data (book, thesis, workshop, and review); 2) biscuits for animals; 3) biscuit ingredients studies only; and 4) biscuits dough studies only. After this, there were 107 articles left to include in the qualitative synthesis (Fig. 1).

For the quantitative synthesis (meta-analysis), 65 articles were excluded due to the following reasons: 1) physical, sensorial, and rheological studies only; 2) clinical trials studies only; and 3) studies that did not determine jointly proteins, fats, ashes, carbohydrates, and fibers contents. Finally, 42 articles were included (Fig. 1).

One hundred and seven articles were identified for the systematic review, from which sixty-nine were based on partial or total substitution of wheat flour by other flours
(Table 1). From the sixty-nine substituted wheat flour biscuits, twenty-nine were based on total substitution of wheat flour. Besides, 20/107 and 11/107 dealt with, respectively, the high amount of sugar and fat in biscuits (Tables 1 and 2). Finally, 19 / 107 articles were based on the use of biscuits in clinical trials (Table 3).

\section{Synthesis of improvement studies}

A listing of materials used to improve the nutritional quality of biscuits is summarized in Table 1 . They includes, mushroom (Biao et al. 2020; Jung \& Joo 2010), banana flour (Ovando-Martinez et al. 2009), pigeon pea flour (Adeola \& Ohizua 2018; Silky \& Tiwari 2014), sweet potato (Adeola \& Ohizua 2018; Adeyeye \& Akingbala 2015; Onabanjo \& Ighere 2014), cheese (Swapna \& Jayaraj Rao 2016), tigernut (Chinma et al. 2011), flaxeed (Hassan et al. 2012), fenugreek seeds (Hooda \& Jood 2005), grape (Karnopp et al. 2015; Kuchtová et al. 2016, 2018), fish and crustacean (Ibrahim 2009; Abou-Zaid and Elbandy 2014), hemp flour (Radočaj et al. 2014), and decaffeinated green tea leaves (Radočaj et al. 2014). In addition, several by-products such as germ, and peel (Martin-Diana et al. 2016) have been used in partial substitution of cereal flour in the formula of biscuit. 
Table 1 Improved materials used to substitute wheat flour in biscuit production

\begin{tabular}{|c|c|c|c|}
\hline Product added & Improvement elements & $\begin{array}{l}\text { Substitution } \\
\text { level (\%) }\end{array}$ & Reference \\
\hline Buckwheat & $\begin{array}{l}\text { Processing properties, sensory, and textural } \\
\text { characteristics, protein content, and gluten-free } \\
\text { biscuits }\end{array}$ & $50-100$ & $\begin{array}{l}\text { Sedej et al. 2011; Torbica et al. 2012; Hadnađev et al. } \\
\text { 2013; Mancebo et al. 2015; Kaur et al. } 2015\end{array}$ \\
\hline Sorghum & $\begin{array}{l}\text { Dietary fiber and low calorie; Fat, protein, ash, } \\
\text { and calorific values as compared to wheat } \\
\text { biscuits }\end{array}$ & $\begin{array}{l}25-45,50, \\
\text { and } 100\end{array}$ & $\begin{array}{l}\text { Okpala \& Okoli 2011; Banerjee et al. 2014; Rai et al. 2014; } \\
\text { Songré-Ouattara et al. 2016, } 2017\end{array}$ \\
\hline Maize & Gluten-free biscuits & 100 & Rai et al. 2014; Mancebo et al. 2015 \\
\hline Rice & $\begin{array}{l}\text { Processing properties, sensory, and textural } \\
\text { characteristics, gluten-free biscuits }\end{array}$ & $50-100$ & $\begin{array}{l}\text { Ceesay et al. 1997; Torbica et al. 2012; Hadnađev et al. } \\
\text { 2013; Radočaj et al. 2014; Rai et al. 2014; Mancebo et al. } \\
\text { 2015; Benkadri et al. 2018; Sulieman et al. } 2019\end{array}$ \\
\hline Pearl millet & $\begin{array}{l}\text { Fat, protein, ash, and calorific values as compared } \\
\text { to wheat biscuits }\end{array}$ & 100 & Rai et al. 2014 \\
\hline Foxtail millet flour & Low phytates and tannins, increased polyphenols & 9 & Singh \& Kumar 2017 \\
\hline Copra & Fiber and protein contents & 51 & Singh et al. Singh \& Kumar 2017 \\
\hline Pea & Protein, fat, iron, and crude fiber contents & $5-100$ & $\begin{array}{l}\text { (Adeola \& Ohizua 2018, Benkadri et al. } 2018 \text { Chinma } \\
\text { et al. 2011, Dhankhar et al. 2019, Han et al. 2010, Okpala } \\
\text { \& Okoli 2011, Silky \& Tiwari 2014, Zucco et al. 2011) }\end{array}$ \\
\hline Bean & Physical and nutritional characteristics & $\begin{array}{l}25,50,75 \\
\text { and } 100\end{array}$ & Han et al. 2010; Zucco et al. 2011 \\
\hline Lentil & Physical and nutritional characteristics & 100 & Han et al. 2010; Zucco et al. 2011 \\
\hline Potato & $\begin{array}{l}\text { Protein, fat, minerals, crude fiber, staling, flavor, } \\
\text { ash, and sugar }\end{array}$ & $\begin{array}{l}10,14,16 \\
18-100\end{array}$ & $\begin{array}{l}\text { (Abou-Zaid \& Elbandy 2014; Onabanjo \& Ighere 2014; } \\
\text { Adeyeye \& Akingbala 2015; Songré-Ouattara et al. 2016; } \\
\text { Adeola \& Ohizua 2018; Sulieman et al. 2019) }\end{array}$ \\
\hline Cheese & $\begin{array}{l}\text { Digestible source of fat and protein and rich } \\
\text { source of vitamin A, B2 and B12 and highly } \\
\text { bioavailable minerals as calcium and zinc }\end{array}$ & $\begin{array}{l}30,40, \text { and } \\
50\end{array}$ & Swapna \& Jayaraj Rao 2016 \\
\hline Date powder & Fiber & $\begin{array}{l}10,20,30 \\
\text { and } 40\end{array}$ & Dhankhar et al. 2019 \\
\hline Soy & $\begin{array}{l}\text { Protein, anti-nutrients, amino acids and vitamins } \\
\text { profile and sensory evaluation }\end{array}$ & $\begin{array}{l}5,10,15, \text { and } \\
20\end{array}$ & $\begin{array}{l}\text { Hu et al. 2013, Loo et al. 2017; Ghoshal \& Kaushik 2020, } \\
\text { Adeyeye } 2020\end{array}$ \\
\hline Flaxseed & $\begin{array}{l}\omega-3 \text { (a-linolenic acid), dietary soluble and } \\
\text { insoluble fibers and lignans }\end{array}$ & $\begin{array}{l}5,12,15,30 \\
50, \text { and } 75\end{array}$ & $\begin{array}{l}\text { Hassan et al. 2012; Coutinho de Moura et al. 2014; } \\
\text { Austria et al. 2016; Omran et al. 2016; Kuang et al. } 2020\end{array}$ \\
\hline Almond & Bioactive components & - & $\begin{array}{l}\text { Jung et al. 2018; Bowen et al. 2019; Pasqualone et al. } \\
2020\end{array}$ \\
\hline Groundnut & Energy, protein, calcium, and iron & - & Ceesay et al. 1997 \\
\hline Fenugreek & $\begin{array}{l}\text { Protein, lysine, dietary fiber, Ca, Fe, alkaloids, } \\
\text { flavonoids, and saponins }\end{array}$ & 5,10 , and 15 & Hooda \& Jood 2005 \\
\hline Mushrooms & $\begin{array}{l}\text { Protein, fiber, ash, fat, potassium, phosphorus, } \\
\text { magnesium, calcium, vitamin B3, vitamin C, } \\
\text { texture, flavor, and sensory acceptability }\end{array}$ & $\begin{array}{l}5,10,15, \text { and } \\
20\end{array}$ & Ayo et al. 2018; Biao et al. 2020 \\
\hline Acha & Carbohydrate & 100 & Ayo et al. 2018 \\
\hline Cocoyam & Carbohydrate & 100 & Okpala \& Okoli 2011; Akujobi 2018 \\
\hline Tigernut flour & $\begin{array}{l}\text { Protein, magnesium, iron, zinc, vitamin E, vitamin } \\
A \text {, and folic acid }\end{array}$ & $\begin{array}{l}30,50,70,80 \\
85,90 \text { and } 95\end{array}$ & Chinma et al. 2011; Akujobi 2018 \\
\hline Gums & $\begin{array}{l}\text { Effect of gums addition on color, appearance and } \\
\text { flavor and overall acceptability }\end{array}$ & 100 & Kaur et al. 2015 \\
\hline $\begin{array}{l}\text { Multi-micronutrients } \\
\text { (Iron, zinc, iodine, and } \\
\text { vitamin A) }\end{array}$ & Iron, zinc, iodine, and vitamin A content & - & Nga et al. 2009, 2011; Songré-Ouattara et al. 2016 \\
\hline Amaranth flours & $\begin{array}{l}\text { Amino acid profile and high bioavailability of } \\
\text { protein }\end{array}$ & $\begin{array}{l}13,20 \text {, and } \\
40\end{array}$ & De la Barca et al. 2010; Singh \& Kumar 2017 \\
\hline Fish and crustacean & Lysine, amino acids & 3,5 , and 6 & Ibrahim 2009; Abou-Zaid \& Elbandy 2014 \\
\hline
\end{tabular}


Table 1 Improved materials used to substitute wheat flour in biscuit production (Continued)

\begin{tabular}{|c|c|c|c|}
\hline Product added & Improvement elements & $\begin{array}{l}\text { Substitution } \\
\text { level (\%) }\end{array}$ & Reference \\
\hline Grape (skin and seeds) & $\begin{array}{l}\text { Proteins, ash, lipids, carbohydrates, vitamins, and } \\
\text { phenolic compounds (tannins, phenolic acids, } \\
\text { anthocyanins, and resveratrol) }\end{array}$ & 15 & Karnopp et al. 2015; Kuchtová et al. 2016, 2018 \\
\hline Moringa & Carotenoid, protein, and dietary fiber & 5,10 , and 15 & Songré-Ouattara et al. 2016, 2017 \\
\hline Spirulina & Carotenoid & 4,6 , and 8 & Songré-Ouattara et al. 2016, 2017 \\
\hline Hemp flour & $\begin{array}{l}\text { Protein, crude fibers, minerals, and essential fatty } \\
\text { acids }\end{array}$ & $\begin{array}{l}10,20,30 \\
\text { and } 40\end{array}$ & Radočaj et al. 2014 \\
\hline Okra powder & Protein, ash, and fiber & $\begin{array}{l}5,10,15,20, \\
\text { and } 25\end{array}$ & Akoja \& Coker 2018 \\
\hline Tea leaves & Protein, fiber, minerals, and antioxidant properties & $\begin{array}{l}2.67,2.02 \\
1.35, \text { and } 0.68\end{array}$ & Radočaj et al. 2014 \\
\hline Mustard meal & $\begin{array}{l}\text { Sensory quality maintained, nutritional and } \\
\text { functional properties improved }\end{array}$ & $\begin{array}{l}5,10,15,20 \\
25 \text { and } 30\end{array}$ & Hassan et al. 2012 \\
\hline Barley meal & $\begin{array}{l}\text { Sensory quality maintained, nutritional and } \\
\text { functional properties improved }\end{array}$ & $\begin{array}{l}5,10,15,20 \\
25 \text { and } 30\end{array}$ & Hassan et al. 2012 \\
\hline Teff flour & $\begin{array}{l}\text { Essential amino acids, iron, calcium, copper, zinc, } \\
\text { aluminum, and barium }\end{array}$ & $\begin{array}{l}10,20,40 \\
\text { and } 100\end{array}$ & Coleman et al. 2013; Mancebo et al. 2015 \\
\hline Oat (flour and bran) & $\begin{array}{l}\text { Influence of different packaging on the storage } \\
\text { period, fibers content }\end{array}$ & 100 & $\begin{array}{l}\text { Serial et al. 2016; Swapna \& Jayaraj Rao 2016; Lee \& Kang } \\
\text { 2018; Duta et al. } 2019\end{array}$ \\
\hline Inulin & Fibers content & - & Serial et al. 2016 \\
\hline Whey protein & $\begin{array}{l}\text { Dietary fiber, protein, lipids, carbohydrate, sugar } \\
\text { and energy }\end{array}$ & 25 & Aggarwal et al. 2016, Hassanzadeh-Rostami et al. 2020 \\
\hline $\begin{array}{l}\text { Agaricus bisporus } \\
\text { polysaccharide }\end{array}$ & Ash, protein, fat and total dietary fibers & 3,6 , and 9 & Sulieman et al. 2019 \\
\hline $\begin{array}{l}\text { Banana (flour and } \\
\text { peel) }\end{array}$ & $\begin{array}{l}\text { Phenolic compound, starch digestibility, and } \\
\text { glycemic index }\end{array}$ & $\begin{array}{l}5,10,15,30 \\
45, \text { and } 50\end{array}$ & $\begin{array}{l}\text { Ovando-Martinez et al. 2009; Agama-Acevedo et al. 2012; } \\
\text { Arun et al. 2015; Adeola \& Ohizua } 2018\end{array}$ \\
\hline Mango peel & Dietary fiber, polyphenols and carotenoids & $\begin{array}{l}5,7.5,10,15 \\
\text { and } 20\end{array}$ & Ajila et al. 2008 \\
\hline $\begin{array}{l}\text { Fruit and vegetable } \\
\text { residue }\end{array}$ & Fiber and mineral & $\begin{array}{l}20,25, \text { and } \\
35\end{array}$ & Ferreira et al. 2013 \\
\hline $\begin{array}{l}\text { Citrus (orange and } \\
\text { lemon) by-products }\end{array}$ & Dietary fiber & $\begin{array}{l}0,5,10, \text { and } \\
15\end{array}$ & Kohajdova et al. 2011 \\
\hline $\begin{array}{l}\text { Grapefruits by- } \\
\text { products }\end{array}$ & Dietary fiber & 5,10 , and 15 & Kohajdova et al. 2013 \\
\hline $\begin{array}{l}\text { Watermelon rind } \\
\text { powder }\end{array}$ & $\begin{array}{l}\text { Dietary fiber, total phenolic content, glycemic } \\
\text { index, and antioxidant activity }\end{array}$ & $\begin{array}{l}10,20, \text { and } \\
30\end{array}$ & Naknaen et al. 2016 \\
\hline Sour cherry pomace & $\begin{array}{l}\text { Total polyphenols, total anthocyanins, and } \\
\text { antioxidant activity }\end{array}$ & 10 and 15 & Šaponjac et al. 2016 \\
\hline Berries pomace & Linoleic acid and a -linolenic acid & 20 and 30 & Šarić et al. 2016 \\
\hline Pomegranate peel & $\begin{array}{l}\text { Protein, dietary fiber, minerals, antioxidant activity, } \\
\text { and } \beta \text {-carotene content }\end{array}$ & 10 & Srivastava et al. 2014 \\
\hline Apple pomace & $\begin{array}{l}\text { Antioxidant properties, total dietary fiber, and } \\
\text { minerals content }\end{array}$ & $\begin{array}{l}3,6,9,15 \\
\text { and } 20\end{array}$ & Mir et al. 2015; Sudha et al. 2016 \\
\hline Olive pomace & Polyphenols and fiber & - & Conterno et al. 2019 \\
\hline $\begin{array}{l}\text { Pomace of } \\
\text { rowanberry, rosehip, } \\
\text { blackcurrant, and } \\
\text { elderberry }\end{array}$ & Dietary fiber, vitamins, and phenolic compounds & 20 & Tańska et al. 2016 \\
\hline Pumpkin & Dietary fiber & 10 and 15 & Turksoy \& Ozkaya 2011 \\
\hline Carrot pomace & Dietary fiber & 10 and 15 & Turksoy \& Ozkaya 2011 \\
\hline
\end{tabular}


Table 1 Improved materials used to substitute wheat flour in biscuit production (Continued)

\begin{tabular}{|c|c|c|c|}
\hline Product added & Improvement elements & $\begin{array}{l}\text { Substitution } \\
\text { level (\%) }\end{array}$ & Reference \\
\hline $\begin{array}{l}\text { Carob by-products } \\
\text { (germ and seed peel) }\end{array}$ & Protein, fiber and antioxidant activity & $\begin{array}{l}\text { Carob peel: } \\
\text { 0-9; Carob } \\
\text { germ: 0-18 }\end{array}$ & Martin-Diana et al. 2016 \\
\hline Beet molasses & Biscuit spread, fracturability, and storability & $10-50$ & Filipčev et al. 2014, 2015 \\
\hline $\begin{array}{l}\text { Glucomannan and } \\
\text { xanthan }\end{array}$ & Fiber content & - & Jenkins et al. 2008 \\
\hline Plant Stanol Ester & Phytosterols & - & Kriengsinyos et al. 2015 \\
\hline $\begin{array}{l}\text { Fructo- } \\
\text { oligosaccharides }\end{array}$ & Fiber content & 20 & Tuohy et al. 2001 \\
\hline $\begin{array}{l}\text { Gum (guar and } \\
\text { xanthan) }\end{array}$ & Technological properties, fiber content & 11 & Tuohy et al. 2001; Benkadri et al. 2018 \\
\hline
\end{tabular}

Among the 69 articles based on the substitution of flour that are included in this study, rice (Benkadri et al. 2018; Ceesay et al. 1997; Hadnađev et al 2013; Mancebo et al. 2015; Radočaj et al. 2014; Rai et al. 2014; Sulieman et al. 2019; Torbica et al. 2012), pea (Han et al. 2010; Chinma et al. 2011; Okpala \& Okoli 2011; Zucco et al. 2011; Silky \& Tiwari 2014; Adeola \& Ohizua 2018; Benkadri et al. 2018; Dhankhar et al. 2019, potato (Abou-Zaid \& Elbandy 2014; Onabanjo \& Ighere 2014; Adeyeye \& Akingbala 2015; Songré-Ouattara et al. 2016; Adeola \& Ohizua 2018; Sulieman et al. 2019), sorghum (Banerjee et al. 2014; Okpala \& Okoli 2011; Rai et al. 2014; Songré-Ouattara et al. 2016, 2017), buckwheat (Hadnađev et al. 2013; Kaur et al. 2015; Mancebo et al. 2015; Sedej et al. 2011; Torbica et al. 2012), and flaxseed (Hassan et al. 2012; Coutinho de Moura et al. 2014; Austria et al. 2016; Kuang et al. 2020; Omran et al. 2016) have received more attention (Table 1).

\section{Quantitative synthesis}

The Principal Component Analysis (PCA) performed with FactoMineR and FactoExtra package of the RStudio software, version 4.1.4 on the proximate composition of 42 biscuits (Fig. 2) showed a spread of individual trees along the main axes, which explained $74.7 \%$ of the total variation, with $47.5 \%$ of variation associated to dimension 1 and $27.2 \%$ to dimension 2 . The dispersion along dimension 1 was mainly related to ash, protein, carbohydrate, and crude fiber; while the dispersion along dimension 2 was mainly linked to variation in fat content. The PCA biplot gives four classes of biscuits. Wheat biscuits (C1, C5, C7), wheat fortified biscuits (W1, W8, W9), all sweet potato biscuits (SP1-SP4), aya biscuits (A1-A3), sorghum biscuit (S1), rice biscuits (R1-R3), cocoyam biscuits (Cy1) seemed to be more similar between to one another for high carbohydrate content, less fiber, less protein, and less ash content, as revealed by the PCA

Table 2 Sugar substitutes and their potential effect on biscuit quality

\begin{tabular}{|c|c|c|c|c|}
\hline $\begin{array}{l}\text { Sugar } \\
\text { substitute }\end{array}$ & Nature & Sugar rate $(\%)$ & Results & References \\
\hline $\begin{array}{l}\text { Maltitol and } \\
\text { FOS-Sucralose }\end{array}$ & & 100 & & Aggarwal et al. 2016 \\
\hline Raftilose & Oligofructose & 20 & Reduce sugar content & Gallagher et al. 2003 \\
\hline Stevia & $\begin{array}{l}\text { S. rebaudiana } \\
\text { leaves }\end{array}$ & $\begin{array}{l}0.06-0.08-0.1-0.14 \\
25,50,75, \text { and } 100\end{array}$ & $\begin{array}{l}\text { High fiber content, angiotensin-converting enzyme } \\
\text { and a-amylase inhibitory activity, and antioxidant } \\
\text { effect }\end{array}$ & $\begin{array}{l}\text { Vatankhah et al. 2015; Pourmohammadi } \\
\text { et al. 2017; Góngora Salazar et al. } 2018\end{array}$ \\
\hline Erythritol & Sweetener & $25,50,75$, and 100 & $\begin{array}{l}\text { Partial replacement of sucrose with up to } 50 \% \\
\text { erythritol had sensory and physical quality } \\
\text { characteristics comparable with cookies prepared } \\
\text { with } 100 \% \text { sucrose }\end{array}$ & Lin et al. 2010 \\
\hline $\begin{array}{l}\text { Arabinoxylan } \\
\text { oligosaccharides }\end{array}$ & $\begin{array}{l}\text { Complex } \\
\text { carbohydrates }\end{array}$ & 30 & Reduction of sucrose and increase of fiber levels & Pareyt et al. 2011 \\
\hline Isomalt & Polyol & $3,6,9$, and 12 & Reduction of sucrose & Pourmohammadi et al. 2017 \\
\hline Maltodextrin & Starch & $2.5-5-7.5-10$ & Reduction of sucrose & Pourmohammadi et al. 2017 \\
\hline $\begin{array}{l}\text { Isomalt, } \\
\text { maltodextrin, } \\
\text { stevia }\end{array}$ & - & $6-2.5-0.06$ & $\begin{array}{l}\text { Biscuits were more comparable to one elaborate } \\
\text { with sucrose, and with the highest acceptance } \\
\text { level in sensory evaluations }\end{array}$ & Pourmohammadi et al. 2017 \\
\hline
\end{tabular}


Table 3 Shortening substitutes and their potential effect on biscuit quality

\begin{tabular}{|c|c|c|c|c|}
\hline $\begin{array}{l}\text { Fat } \\
\text { substitute }\end{array}$ & Nature & $\begin{array}{l}\text { Substitution } \\
\text { rate }(\%)\end{array}$ & Results & References \\
\hline Inulin & $\begin{array}{l}\text { Non- } \\
\text { digestible } \\
\text { dietary fiber }\end{array}$ & 20 and 25 & $\begin{array}{l}\text { Textural and sensory properties maintained; Dietary fiber } \\
\text { increased, weakened lubrication of biscuit dough, } \\
\text { reduction of energy density }\end{array}$ & $\begin{array}{l}\text { Rodríguez-García et al. 2013; Błońska et al. 2014; } \\
\text { Banerjee et al. 2014; Krystyjan et al. 2015; Onacik- } \\
\text { Gür et al. 2015; Canalis et al. } 2017\end{array}$ \\
\hline Rice starch & $\begin{array}{l}\text { Complex } \\
\text { carbohydrates }\end{array}$ & 20 & Native and modified rice starch effective & Lee \& Puligundla 2016 \\
\hline Corn fiber & $\begin{array}{l}\text { Complex } \\
\text { carbohydrates }\end{array}$ & 30 & Fat reduction and fiber fortification & Forker et al. 2012 \\
\hline Lupine extract & $\begin{array}{l}\text { Complex } \\
\text { carbohydrates }\end{array}$ & 30 & Fat reduction and fiber fortification & Forker et al. 2012 \\
\hline $\begin{array}{l}\text { Wheat bran } \\
\text { fibers }\end{array}$ & Plant fibers & $\begin{array}{l}10,20 \text {, and } \\
30\end{array}$ & $\begin{array}{l}\text { Texture of biscuits was greatly dependent on the texture } \\
\text { of the dough }\end{array}$ & Erinc et al. 2018 \\
\hline $\begin{array}{l}\text { Candelilla } \\
\text { wax-canola oil } \\
\text { oleogels }\end{array}$ & Oil & $30-40$ & Decrease of saturated fatty acids $(63.4 \% \rightarrow 32.3 \%)$ & Jang et al. 2015 \\
\hline $\begin{array}{l}\text { Puree of } \\
\text { canned green } \\
\text { peas }\end{array}$ & & 75 & Sensory assessment & Romanchik-Cerpovicz et al. 2018 \\
\hline Lecithin & & 3 & $\begin{array}{l}\text { Lecithin ( } 3 \% \text {, sunflower based) achieved similar sensory } \\
\text { quality as fat biscuit }\end{array}$ & Onacik-Gür et al. 2015 \\
\hline Maltodextrin & $\begin{array}{l}\text { Complex } \\
\text { carbohydrates }\end{array}$ & $\begin{array}{l}50,60, \text { and } \\
70\end{array}$ & Texture maintained, low-fat biscuit & Sudha et al. 2007; Chugh et al. 2013 \\
\hline Guar gum & $\begin{array}{l}\text { Complex } \\
\text { carbohydrates }\end{array}$ & - & Low-fat biscuit & Chugh et al. 2013 \\
\hline Polydextrose & $\begin{array}{l}\text { Complex } \\
\text { carbohydrates }\end{array}$ & $\begin{array}{l}50,60, \text { and } \\
70\end{array}$ & Texture maintained & Sudha et al. 2007, Aggarwal et al. 2016 \\
\hline Red palm oil & Oil & - & $\beta$-carotene & van Stuijvenberg et al. 2001 \\
\hline Goat fat & Oil & 100 & Functional and nutritional properties increased & Costa et al. 2019 \\
\hline Flax oil & Oil & 100 & $\omega-3$ fatty acids & Hassan et al. 2012 \\
\hline Sunflower oil & Oil & 100 & Free of trans and low-saturated fats & Tarancon et al. 2013; Onacik-Gür et al. 2015 \\
\hline Olive oil & Oil & 100 & Free of trans and low-saturated fats & Tarancón et al. Tarancon et al. 2013 \\
\hline
\end{tabular}

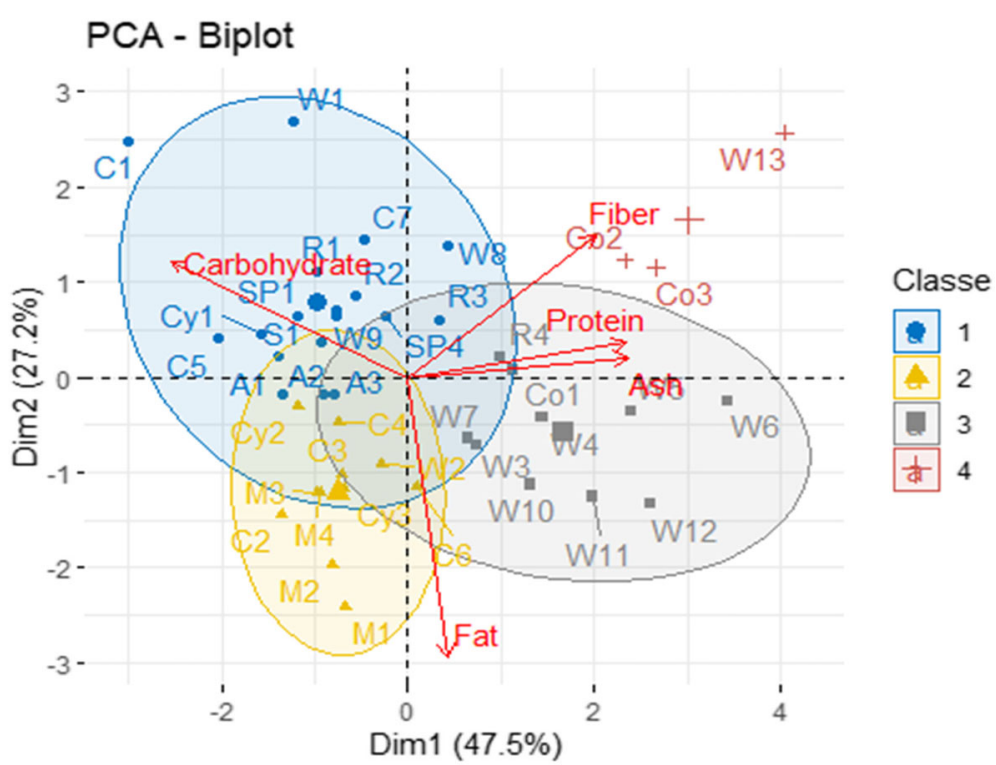

Fig. 2 PCA biplot of the proximate composition to 42 biscuits 
biplot (Fig. 2). Also, wheat biscuits (C2, C3, and C6), wheat fortified biscuits (W2), all maize and maize fortified biscuits (M1-M4), and cocoyam biscuits (Cy2 and $\mathrm{Cy} 3$ ) seemed to be more similar to one another for high fat content. The third class of biscuit included wheat fortified biscuits (W3-W7, and W10-W12), copra and foxtail millet biscuits (Co1), and rice fortified biscuits (R4) with high content of protein, ashes and fiber. The PCA analysis revealed a last group of three biscuits (W13, $\mathrm{Co} 2$ and Co3) that seemed to be more similar to one another for high content of fiber.

The Hierarchical Ascending Classification (HAC) or dendrogram performed with FactoMineR and FactoExtra package of the RStudio software, version 4.1.4 on the proximate composition of the 42 biscuits is shown in Fig. 3 and gives four classes of biscuits. The first group consisted of biscuits W13, Co2 and Co3. They contain the highest fiber content. The second group is represented by the biscuits R3, R4, Co1, W7, W3, W4, W5, W6, W10, W11, and W12 which revealed the highest proteins contents. The third group counted M3, M4, M1, M2, Cy3, C6, C2, C3, and W2 and presented the highest lipids contents. At last, the fourth group was composed of biscuits C1, W1, C4, A1, A2, A3, W9, S1,
C5, Cy1, Cy2, W8, C7, R1, R2, SP4, SP1, SP2, and SP3 and were characterized by the highest carbohydrates contents.

All of the biscuits included in the PCA and HAC analyses had a good acceptability (Dhankhar et al. 2019; Omran et al. 2016; Singh \& Kumar 2017).

The code associated with each point is the unique identifier of each biscuit: $\mathrm{C}=$ control biscuits, with wheat as the only flour constituent (Akoja \& Coker 2018; Ayo et al. 2018; Banerjee et al. 2014; Coutinho de Moura et al. 2014; Dhankhar et al. 2019; Hu et al. 2013; Omran et al. 2016), $W=$ wheat based biscuits, with wheat as the majority of the flour and with additional improvement constituent (Akoja \& Coker 2018; Coutinho de Moura et al. 2014; Dhankhar et al. 2019; Omran et al. 2016), S= Sorghum or sorghum based biscuits (Banerjee et al. 2014; Songré-Ouattara et al. 2017), $M=$ maize or maize based biscuits (Costa et al. 2019), SP $=$ sweet potato or sweet potato based biscuits (Sulieman et al. 2019), Co = copra and foxtail millet or their based biscuits (Singh \& Kumar 2017), $\mathrm{R}=$ rice or rice based biscuits (Adeyeye 2020), $\mathrm{Cy}=$ cocoyam or cocoyam based biscuits (Akujobi 2018), A = acha or acha based biscuits (Ayo et al. 2018). The different circles represent the three populations

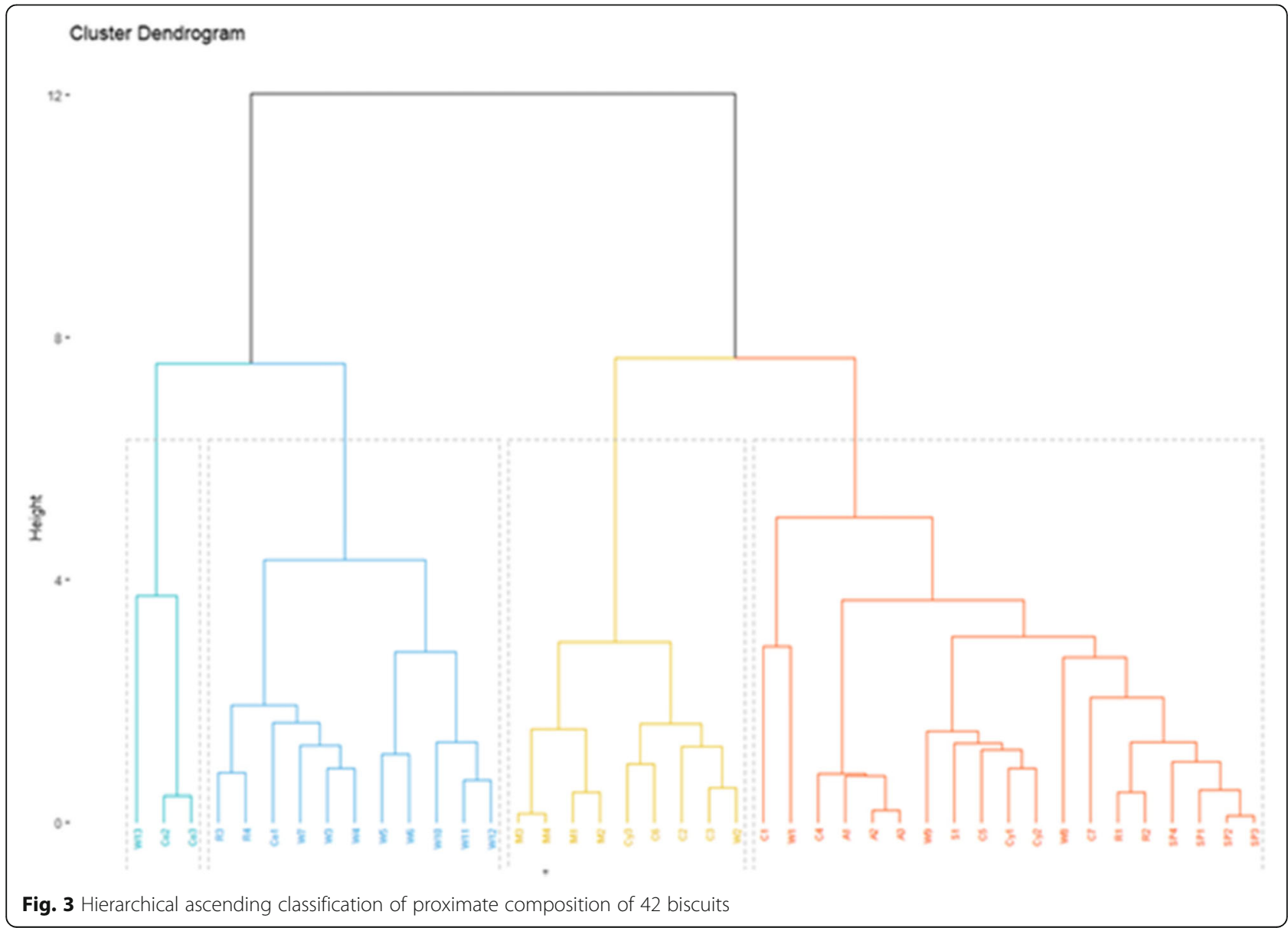


studied. Vectors show the relative weight of the variables moisture, ashes, lipids, proteins and carbohydrates, which determines the spread of points (individual trees) on the biplot.

\section{Biscuit and potential health benefits}

Several studies have been carried out on the potential health benefits of biscuits for humans. These studies focused on the reduction or the substitution of sugar (Table 2) and / or shortening (Table 3) in biscuits production, the use of gluten-free flour as a substitute of wheat flour (Table 1), and the use of biscuits in clinical trials to combat or prevent some diseases (Table 4).

Considering the well-known deleterious consequences of sugar and fat in biscuits, there are more and more, several nutritive products that can replace sugar and fat in biscuits formulation with effect to decrease the calories, keep the sucrose and fat functionalities, and improve the nutritional values (dietary fiber, bioactive compounds, and minerals) (Tables 2 and 3 ).

For sugar substitutes, the nutritive sweeteners include maltitol, FOS-sucralose, isomalt, erythritol, arabinoxylan oligosaccharides, maltodextrin, and stevia (Gallagher et al. 2003; Lin et al. 2010; Pareyt et al. 2011; Vatankhah et al. 2015; Aggarwal et al. Aggarwal et al. 2016; Pourmohammadi et al. 2017; Góngora Salazar et al. 2018). Stevia is the most used as sugar substitute (Vatankhah et al. 2015; Pourmohammadi et al. 2017; Góngora Salazar et al. 2018).

Several materials have been used during biscuit processing for fat substitution and include inulin (Banerjee et al. 2014; Błońska et al. 2014; Canalis et al. 2017; Krystyjan et al. 2015; Onacik-Gür et al. 2015; Rodríguez-García et al. 2013), rice starch (Lee \& Puligundla 2016), corn fiber (Forker et al. 2012), polydextrose (Aggarwal et al. 2016; Sudha et al. 2007), sunflower oil (Onacik-Gür et al. 2015; Tarancon et al. 2013), lecithin (Onacik-Gür et al. 2015), puree of canned green peas (Romanchik-Cerpovicz et al. 2018), candelilla wax-canola oil oleogels (Jang et al. 2015), maltodextrin (Chugh et al. 2013; Sudha et al. 2007), guar gum (Chugh et al. 2013), lupine extract (Forker et al. 2012), wheat bran fibers (Erinc et al. 2018), red palm oil (van Stuijvenberg et al. 2001), goat fat (Costa et al. 2019), flax oil (Hassan et al. 2012), and olive oil (Tarancón et al. Tarancon et al. 2013). Among them, inulin (Banerjee et al. 2014; Błońska et al. 2014; Canalis et al. 2017; Krystyjan et al. 2015; Onacik-Gür et al. 2015; Rodríguez-García et al. 2013), polydextrose (Aggarwal et al. 2016; Sudha et al. 2007), maltodextrin (Chugh et al. 2013; Sudha et al., 2007), and sunflower oil (Onacik-Gür et al. 2015; Tarancon et al. 2013) are the most used.

The use of biscuits in clinical trials has focused on the fight against some diseases but also on the evaluating of the effects of other foods ingredients on human health. It includes micronutrient deficiency (Nga et al. 2009, Bouhouch et al. 2016, Jung et al. 2018), weight loss (Hassanzadeh-Rostami et al. 2020; Hu et al. 2013; Kuang et al. 2020), type 2 diabetes (Bowen et al. 2019; Jenkins et al. 2008), post-prandial folate bioavailability (Buffière et al. 2020), serum cholesterol reduction efficacy (Kriengsinyos et al. 2015), birth weight and perinatal mortality (Ceesay et al. 1997), parasitic infections (Nga et al. 2011), gastrointestinal symptoms and autism spectrum disorders (Ghalichi et al. 2016), prebiotics effect (Tuohy et al. 2001), and neurocognitive outcomes (Loo et al. 2017) (Table 4). Biscuit has been used as a vehicle for specified nutrients, such as vitamins and minerals.

\section{Discussion}

\section{Improving the nutritional quality of biscuits}

The improvement in biscuit quality involves primarily novel recipes, process improvement, nutritional enrichment, and health promotion, as summarized in the following headlines.

\section{Total and partial substitution of wheat flour}

Wheat is the main source of flour used to produce biscuits (Chavan et al. 1993; Denis 2011). However, the nutritional quality of wheat flour is known to be limited (Chavan et al. 1993). Indeed, several bioactive components are unevenly distributed in wheat grains (Table 1 ). For example, around 50 to $60 \%$ of the minerals and vitamins are distributed in the bran, aleurone, and germ (Chavan et al. 1993). Consequently, these components are partially or totally removed during milling, leading to lower nutritional quality biscuits (Chavan et al. 1993). Therefore, it is proposed to use whole-grain flour to preserve the nutrients from the bran. Nonetheless, wheat grains still have protein quality inferior to most cereals (Chavan et al. 1993). Protein from wheat flour is a poor source of lysine, methionine, and threonine (Chavan et al. 1993). Refined wheat flour has more reduced nutritional quality with very low protein quality (Chavan et al. 1993). Another factor to be considered as limiting the nutritional quality of wheat flour is the presence of gluten. The high content of gluten in wheat flour has been a concern in public health due to gluten sensitivity, allergies, and coeliac disease (Mancebo et al. 2015; Rosell et al. 2014).

Given the concern with wheat flour's nutritional quality, alternative flours have been explored (Benkadri et al. 2018; Chung et al. 2014; Mancebo et al. 2015). Wheat flour has been partially or totally substituted. Also, the sweet potato, the amaranth, the buckwheat, the pea and the acha showed to be interesting substitutes for wheat in biscuit production (Han et al. 2010; De la Barca et al. 2010; Hadnađev et al. 
Table 4 The use of biscuit in clinical trial

\begin{tabular}{|c|c|c|c|c|c|}
\hline Health concern & $\begin{array}{l}\text { Additional } \\
\text { product }\end{array}$ & $\begin{array}{l}\text { Additional product } \\
\text { properties }\end{array}$ & $\begin{array}{l}\text { Administration } \\
\text { mode }\end{array}$ & Result & References \\
\hline \multirow[t]{3}{*}{$\begin{array}{l}\text { Micronutrient } \\
\text { deficiency }\end{array}$} & $\begin{array}{l}\text { Multi- } \\
\text { Micronutrient }\end{array}$ & $\begin{array}{l}\text { Improvement of micronutrient } \\
\text { status }\end{array}$ & $\begin{array}{l}30 \mathrm{~g} \text { biscuits, } 5 \\
\text { days/week /4 } \\
\text { months }\end{array}$ & $\begin{array}{l}\text { Improvement of the concentrations of hemoglobin } \\
(+1.87 \mathrm{~g} / \mathrm{L}) \text {, plasma ferritin }(+7.5 \mathrm{mg} / \mathrm{L}) \text {, body iron } \\
(+0.56 \mathrm{mg} / \mathrm{kg} \text { body weight), plasma zinc }(+0.61 \\
\mathrm{mmol} / \mathrm{L}) \text {, plasma retinol }(+0.041 \mathrm{mmol} / \mathrm{L}) \text {, and } \\
\text { urinary iodine }(+22.49 \mathrm{mmol} / \mathrm{L}) ; \text { reduction of the } \\
\text { risk of anemia }(40 \%) \text { and deficiencies of zinc }(40 \%) \\
\text { and iodine }(40 \%) \text {. }\end{array}$ & $\begin{array}{l}\text { Nga et al. } \\
2009\end{array}$ \\
\hline & & Iron fortification & $\begin{array}{l}2 \text { or } 3 \text { biscuits / } \\
6 \mathrm{~d} / \text { week/ } 28 \\
\text { weeks }\end{array}$ & $\begin{array}{l}\text { Improved iron status and reduction of blood lead } \\
\text { concentrations }(4.3 \mu \mathrm{g} / \mathrm{dL} \text { to } 2.9 \mu \mathrm{g} / \mathrm{dL} \text { for } \\
\text { NaFeEDTA) }\end{array}$ & $\begin{array}{l}\text { Bouhouch } \\
\text { et al. } 2016\end{array}$ \\
\hline & Roasted almonds & $\begin{array}{l}\text { Monounsaturated fatty acids, } \\
\text { polyunsaturated fatty acids, } \\
\text { fiber, and vitamin E }\end{array}$ & $\begin{array}{l}56 \mathrm{~g} \text { of almonds } \\
\text { biscuits / day / } \\
4 \text { weeks }\end{array}$ & $\begin{array}{l}\text { Decreased total cholesterol }(5.5 \%) \text {, low-density lipo- } \\
\text { protein cholesterol }(4.6 \%) \text {, and non- high-density } \\
\text { lipoprotein cholesterol }(6.4 \%) \text { and increased plasma } \\
\text { a-tocopherol (8.5\%) compared to the biscuit } \\
\text { control. }\end{array}$ & $\begin{array}{l}\text { Jung et al. } \\
2018\end{array}$ \\
\hline
\end{tabular}

Weight loss Whey protein and Highest satiety feeling wheat bran

Soy fiber

Flaxseed flour

Type 2 diabetes Carbohydrate

Glucomannan and High fiber content xanthan

$\begin{array}{lll}\begin{array}{l}\text { Post-prandial } \\ \text { folate } \\ \text { bioavailability }\end{array} & \text { Folic acid } & \text { Folate plasma availability } \\ \begin{array}{l}\text { Serum cholesterol } \\ \text { reduction efficacy }\end{array} & \text { Plant stanol ester } & \begin{array}{l}\text { Low-density lipoprotein } \\ \text { cholesterol -(LDL-C-) lowering } \\ \text { efficacy }\end{array} \\ \begin{array}{l}\text { Birth weight and } \\ \text { perinatal mortality }\end{array} & \text { groundnut } & \begin{array}{l}\text { Reduce the retardation of fetal } \\ \text { growth }\end{array}\end{array}$

Parasitic infections MultiMicronutrient

Gastrointestinal symptoms and autism spectrum disorders

\section{Gluten-free biscuit Reduction of the prevalence of (GFB) autism spectrum disorders}

Rich source of dietary fiber

Rich source of dietary fiber

Rich source of bioactive components

Decreased parasite load and improved cognitive outcomes

$50 \mathrm{~g} /$ day $/ 8$ weeks

$100 \mathrm{~g} /$ day / 12 weeks

$00 \mathrm{~g}$ of biscuits / day / 60 days

$56 \mathrm{~g} /$ day / 8 weeks

$10 \mathrm{~g} /$ biscuit

$-$

1 biscuit / day / 2 weeks

2 biscuit (4.3 MJ*2)/day / 20 weeks

$30 \mathrm{~g}$ biscuits, 5 days/week / 4 months

Gluten-free diet gastrointestinal symptoms and / 6 weeks behaviors
Control appetite (Composite appetite score: - 3.12), Hassanzadehmore decrease of energy intake $(-1531.13 \mathrm{KJ} /$ day $)$, Rostami et al. body weight $(-2.91 \mathrm{Kg})$, waist circumference $(-\quad 2020$ $4.44 \mathrm{~cm})$, and serum insulin $(-2.31 \mathrm{mlU} / \mathrm{L})$; more increase GLP-1 (+0.05) and more attenuate reduction of HDL-C level $(+1.18 \mathrm{mg} / \mathrm{dl})$ comparatively to control biscuits.

Significant decrease of body weight $(-1.39 \mathrm{~kg})$, Hu et al. body mass index (-0.51), waist circumference $(-\quad 2013$ $1.75 \mathrm{~cm})$, diastolic blood pressure $(-3.82 \mathrm{mmHg})$, serum levels of total cholesterol $(-0.58 \mathrm{mmol} / \mathrm{L})$. LDL-C $(-0.41 \mathrm{mmol} / \mathrm{L})$, and glucose $(-0.95 \mathrm{mmol} /$ L), body fat $(-0.71 \mathrm{~kg})$, and trunk fat $(-0.64 \mathrm{~kg})$ for those who consumed the supplemented biscuits comparatively to those who consumed the control biscuit.

Decrease body weight $(-0.83)$ and lower triacylglycerol levels ( $-0.04 \mathrm{mmol} / \mathrm{L})$ comparatively to control group

Significant reduction of serum total cholesterol/ $\mathrm{HDL}-\mathrm{C}$ ratio in women those consumed almond snack compared to those who consumed biscuit snack $(-0.36 \mathrm{mmol} / \mathrm{L}$ vs. $-0.14 \mathrm{mmol} / \mathrm{L})$

Reduction of the glycemic index by $74 \%$ in healthy participants and by $63 \%$ in participants with diabetes

Biscuit and custard have presented comparable folate bioavailability

Kuang et al. 2020

Bowen et al. 2019

Jenkins et al. 2008

Buffière et al. 2020

Kriengsinyos

Compared to the control, the total cholesterol, $\mathrm{LDL}-\mathrm{C}$, and the $\mathrm{LDL} / \mathrm{HDL}$ ratio had serum reductions of $4.9,6.1$, and $4.3 \%$, respectively

Increased weight gain in pregnancy (136 g) over the whole year and significantly increased birth weight $(11.1 \%$ of babies with low birth weight for the intervention group against $(17 \%$ for the control group).

Decrease of Ascaris (- 2328 eggs per gram of feces) Nga et al. and Hookworm ( -156 eggs per gram of feces) and 2011 improve cognitive outcomes. These values are higher than those of the group consumed placebo (- 1200 for Ascaris and - 144 for Hookworm).

Significant $(P<0.05)$ decrease of the prevalence of gastrointestinal symptoms after intake of GFB (40.57\% vs. $17.10 \%)$ against an insignificant increase in the regular diet group (RD) (42.45\% vs. $44.05 \%)$ GFB also induces a significant decrease in behavioral disorders ( 80.03 vs. 75.82 ) against an insignificant increase in the regular diet group (79.92vs. 80.92). Ghalichi et al.

et al. 2015

Ceesay et al. 1997 2016 
Table 4 The use of biscuit in clinical trial (Continued)

\begin{tabular}{|c|c|c|c|c|c|}
\hline Health concern & $\begin{array}{l}\text { Additional } \\
\text { product }\end{array}$ & $\begin{array}{l}\text { Additional product } \\
\text { properties }\end{array}$ & $\begin{array}{l}\text { Administration } \\
\text { mode }\end{array}$ & Result & References \\
\hline Prebiotics effect & $\begin{array}{l}\text { Partially } \\
\text { hydrolysed guar } \\
\text { gum and fructo- } \\
\text { oligosaccharides }\end{array}$ & Prebiotic effects & $\begin{array}{l}37.5 \mathrm{~g} / \text { day / } \\
21 \text { days }\end{array}$ & $\begin{array}{l}\text { Bifidobacterial numbers increased from } \\
\text { pretreatment levels of } 9.10 \log _{10} \text { cells/g faeces } \\
\text { and placebo levels of } 9.18 \log _{10} \text { cells/g faeces, to } \\
9.59 \log _{10} \text { cells/g faeces after ingestion of the } \\
\text { experimental biscuits. }\end{array}$ & $\begin{array}{l}\text { Tuohy et al. } \\
2001\end{array}$ \\
\hline $\begin{array}{l}\text { Neurocognitive } \\
\text { outcomes }\end{array}$ & Soy protein & $\begin{array}{l}\text { Protein dietary } \\
\text { supplementation }\end{array}$ & $\begin{array}{l}\text { Biscuits } 5 \text { days / } \\
\text { week / } 18 \\
\text { months }\end{array}$ & $\begin{array}{l}\text { Improvements of nonverbal cognitive (fluid } \\
\text { intelligence) performance for children who } \\
\text { received soy protein than those who received ASFs. } \\
\text { For example, beery visual-motor integration for } \\
\text { children who received soy protein is } 7.44 \text { and } 6.70 \\
\text { for children who received beef. }\end{array}$ & $\begin{array}{l}\text { Loo et al. } \\
2017\end{array}$ \\
\hline
\end{tabular}

2013; Mancebo et al. 2015; Kaur et al. 2015; Adeyeye \& Akingbala 2015; Ayo et al. 2018; Adeola \& Ohizua 2018). Moreover, the flours' protein quality has been improved using for example, fish proteins, whey, single-cell proteins, mushroom leaf protein isolates, legumes, and oilseeds (Abou-Zaid \& Elbandy 2014; Biao et al. 2020; Jang et al. 2015). Interestingly, food waste or by-product (e.g., peels, germs, biomass waste such as leaves) are recovered and used as functional ingredients for the formulation of biscuit flour. Subsequently, xanthan gum, guar gum, arabic gum, agarose, $\beta$-glucan, and carboxymethyl cellulose (CMC) have been used to overcome technological aspects (i.e., rheological properties) attributed to gluten (Hadnađev et al. 2013; Songré-Ouattara et al., 2017; Xu et al. 2020).

The partial substitution of cereal flour with specific components has also been used to improve the nutritional quality and the potential health benefits of biscuits (Adeola \& Ohizua 2018; Biao et al. 2020).

\section{Novelties in the processing of improved biscuits}

The improvement of the nutritional values of biscuits can be attributed to several innovations in the processing (Chung et al. 2014; Mancebo et al. 2015). The first challenge is associated with the production of the flour base. The particle size of flour is well known to influence the quality of biscuits (Mancebo et al. 2015). The incorporation of fine flours increases the biscuit hardness and decreases its spread. Besides, the coarse flours impact the biscuit textural (i.e., cohesiveness, spread) and organoleptic properties (i.e., mouthfeels) (Zucco et al. 2011). Subsequently, the flour processing is adapted, with compromise, according to the technological and nutritional aspects. However, refined flour of cereal used in biscuit processing is known to have lower nutritional quality and protein content than the whole cereal grain flour (Mancebo et al. 2015). Furthermore, roasting, precooking, defatting, germination, non-refining, and fermentation have been applied to prepare the ingredients and have also been showed to create novel flavors and improve the nutritional properties of the final biscuits
(Mancebo et al. 2015; Omran et al. 2016; Singh \& Kumar 2017; Sulieman et al. 2019).

Fermentation is a good way of incorporating enrichment ingredient that increases the nutritional quality of biscuits (Sulieman et al. 2019). For instance, using of $6 \%$ of fermented Agaricus bisporus polysaccharide flours in sweet potato and rice biscuits allowed to improve the biscuits' nutritional and functional properties (Sulieman et al. 2019). However, the unfermented Agaricus bisporus polysaccharide flours have to be incorporated at a lower percentage (3\%) to have good acceptability (Sulieman et al. 2019).

On the other hand, the germination of foxtail millet for the production of biscuit resulted in a decrease of anti-nutrients including phytates and tannins (Singh \& Kumar 2017). It induced an increase of polyphenols content in biscuits (Singh \& Kumar 2017). The use of germinated brown rice by partial or complete replacement of wheat flour in the production of biscuit has also led to the improvement of the nutritional quality of the biscuits (Chung et al. 2014).

Defatting has also been used to improve the acceptability of biscuits. This was the case with biscuits produced using defatted flaxseed flour. They were more appreciated than the biscuits produced with whole fat flaxseed flour (Omran et al. 2016).

\section{Nutritional, and sensory quality of improved biscuit}

The association of various cereals and the use of constituents with nutritional and technological interests have improved the nutritional, sensory, and functional properties of biscuits. A short overview of articles that mentioned the nutritional, physico-chemical and sensory quality of biscuits shows that the content of several functional nutrients such as protein, fiber, $\omega-3$ fatty acids, dietary fibers, antioxidants, vitamins, and mineral has been enhanced (Costa et al. 2019; Swapna \& Jayaraj Rao 2016). For example, the biscuits produced with oats and cheese had high nutritive value with 12.53 and $12.89 \%$ protein, 2.70 and $2.75 \%$ minerals and 0.62 and $0.60 \%$ beta-glucan (Swapna \& Jayaraj Rao, 2016). Whole 
wheat combined with sorghum has been used to produce biscuits with good acceptability (ranking 7 on hedonic scale of 9 point) (Banerjee et al. 2014). The acceptability of biscuits can increase with the rate of sorghum ranging from 35 to $40 \%$ (Banerjee et al. 2014). Ghoshal and Kaushik (2020) have produced high protein biscuits, adding defatted soy flour up to $20 \%$ in the formulation without affecting their overall acceptability (Ghoshal \& Kaushik 2020).

Regarding gluten-free biscuits, it is shown that the nonwheat flour sources significantly influenced the overall acceptability, the weight, the moisture and the water activity of the biscuits (Benkadri et al. 2018; Mancebo et al. 2015). Gluten-free flour biscuits have lower spread and greater hardness than wheat flour based-biscuits (Mancebo et al. 2015). The effect of the gums used to compensate the rule of gluten in gluten-free biscuit processing, was investigated by Kaur et al. (2015), who concluded that the qualities of buckwheat biscuits with xanthan gum were comparable to those made with wheat flour (Kaur et al. 2015).

In the case of the use of wholegrain and the substitution of wheat flour, the studies of Sedej et al. (2011) have shown no significant difference from sensory evaluation between the whole buckwheat grain biscuits and wholewheat biscuits (Sedej et al. 2011).

The use of by-product (e.g., pomace and peel) generally increases the nutritional quality of biscuit, specially the content of protein, fiber, minerals, essential fatty acids and antioxidant potential (Martin-Diana et al. 2016). For the physical property, by-products reduce the pasting viscosity and the lightness of the biscuit; but increase the pasting temperature of the biscuit dough (Mir et al. 2015).

The use of improved materials has presented best proximate composition but had lower acceptability (Coutinho de Moura et al. 2014; Songré-Ouattara et al. 2016) due to the change of different sensory parameter such as color, taste, texture, aroma, odor (Fig. 4) (Pasqualone et al. 2020; Šarić et al. 2016; Tańska et al. 2016).
From left to right: Control biscuit prepared with 100\% wheat flour; and biscuits prepared by adding 10 and 20\% of almond skin powder in the level of wheat flour (Pasqualone et al. 2020).

The PCA analysis showed two groups (3 and 4) of biscuits with a good potential for children's diets due to the high protein content and average carbohydrate level. These groups are characterized by biscuits produced with copra and foxtail millet (Co1, Co2 and Co3) blended with amaranth (Singh \& Kumar 2017) and wheat biscuit supplemented with soy fiber (W13) (Hu et al. 2013). The PCA analysis also showed that biscuits produced with 100 and 95\% wheat flour $(\mathrm{C} 1, \mathrm{C} 2, \mathrm{C} 3$, and W1) have high carbohydrate and fat contents.

\section{Biscuit and potential health benefits Control of biscuits' sugar content}

Sugars are the second major constituent of biscuit (Chavan et al. 2016; Sahin et al. 2019; van der Smam \& Renzetti 2019). Biscuits contain a high amount of sugar (10-30\%), which influences their techno-functional properties (e.g. taste and flavor) and increases their shelf-life (Chavan et al. 2016; Serial et al. 2016; van der Smam \& Renzetti 2019). The sugar content significantly influences the organoleptic characteristics of biscuits. Depending on the temperature, the sugar content is responsible for the desired brown color (Perego et al. 2007). The crumbly and crispy textures are due to the undissolved sugar crystals and sugar recrystallization (Pareyt et al. 2009).

The high content of sugar in biscuits makes them high energy density foods, with an energy density of around $5 \mathrm{cal} / \mathrm{g}$ (Banerjee et al. 2014), which is over the recommended energy density for complementary food (4-4,25 cal / g) (CODEX CAC/GL 08 1991). However, for adults, this high energy density food has a concern in public health, because this is often linked with risks of some diseases such as cardiovascular diseases, diabetes, and obesity (Pourmohammadi et al. 2017; van der Smam \&

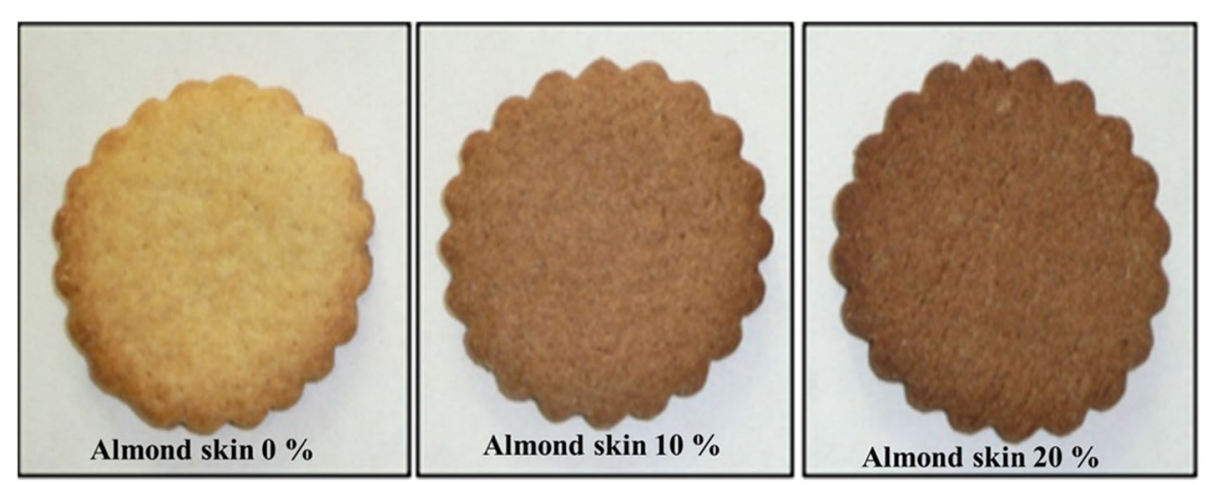

Fig. 4 Biscuits enriched with almond skins showing the change of color 
Renzetti 2019). This public health concern has led many health organizations to encourage the production of biscuits with reduced calories (French Ministry of Health Health 2006; Hercberg et al. 2008; World Health Organization 2015). For example, the WHO guideline recommends reducing the daily intake of free-sugars to 10\% (World Health Organization 2015). In addition, the UK government has recommended bakery products with reduced calories of 20\% (Sahin et al. 2019). Because of worldwide public-health campaigns claiming for no added sugar, biscuits with decreased calories are more and more common in the market (Aggarwal et al. 2016; Biguzzi et al. 2014; Denis 2011).

The decrease of sugar in biscuits formulas tends to alter the texture, sensory and hedonic properties (Biguzzi et al. 2014; Pareyt et al. 2009). A sugar reduction of up to $25 \%$ was linked to a significant of sweetness (Perego et al. 2007). Nevertheless, studies carried out in European countries, mainly France, have identified a significant decrease in the sugar content. This decrease varies between 2 to $15 \mathrm{~g} / 100$ $\mathrm{g}$ in biscuits and cakes (Denis 2011). The studies of Dhankhar et al. (2019) showed that the reduction of sugar level in biscuits could be made up to $60 \%$ by using date powder as a sweetening agent for replacing sugar (Dhankhar et al. 2019).

\section{Control of biscuits' fat content}

Fat is also one of the major constituents of biscuits. This constituent plays a substantial role in the nutritional quality of biscuits by increasing their tenderness and regulating their texture. Fat used in biscuits processing must have specific physicochemical and technological properties such as high melting point and plasticity (Costa et al. 2019; Tarancon et al. 2013). Fat is wellknown to regulate the mechanical and rheological properties of biscuits (Colla et al. 2018). This constituent provides a good smell and taste to biscuits and greatly influences their convenient form and sensory properties. Fat can be from animal (butter, butter oil) or plant (palm oil, peanut oil, etc.) sources (Chavan et al. 2016; Pareyt et al. 2009).

Like sugar, the high fat content in biscuits can make them high energy density foods that are greatly recommended for children as complementary food. However, the high fat content constitutes a concern in public health, because it is often linked with risks of some diseases such as cardiovascular diseases, diabetes, cancer and obesity (Lee \& Puligundla 2016; Okumura et al. 2017). From this point of view many health organizations have also issued recommendations for reducing fat content in food for adults. Besides, people with risks of cardiovascular diseases, diabetes, and obesity are looking to maintain a healthy diet including nutritious biscuits with no fat, low fat, and reduced fat (Colla et al. 2018; Erinc et al. 2018; French Ministry of Health 2006; Hercberg et al. 2008).

Given the above and considering the well-known deleterious consequences of the consumption of biscuits with high fat content, biscuits with fat reduced or without fat (Banerjee et al. 2014; Erinc et al. 2018) which maintain good sensory properties are required in the market. For this purpose, several ingredients have been used as fat substitutes during the biscuit processing (Table 3).

Some examples of fat substitutes include inulin, spreads and milk, b-glucan and amylodextrins, pectin, polydextrose, acetylated rice starch, high-oleic sunflower oil and inulin/ $\beta$-glucan/lecithin, puree of canned green peas, candelilla wax-canola oil oleogels, corn fiber, maltodextrin, guar gum and lupine extractare (Forker et al. 2012; Chugh et al. 2013; Banerjee et al. 2014; Krystyjan et al. 2015; Jang et al. 2015; Onacik-Gür et al. 2015; Lee \& Puligundla 2016; Erinc et al. 2018; Romanchik-Cerpovicz et al. 2018).

\section{Gluten-free biscuits}

The high content of gluten in wheat flour has been a concern in public health due to food allergies, celiac disease and gluten sensitivity (Mancebo et al. 2015; Rosell et al. 2014). Therefore, wheat flour is substituted with several other flours to improve biscuits' quality or prevent glutenassociated health disorders (Table 1). Some gluten-free cereals used in biscuit processing are rice (O. sativa), sorghum (S. vulgare), maize (Z. mays), and several minor grains such as the millets, especially pearl millet ( $P$. glaucum), teff (E. tef), oat (A. sativa) (Adeyeye \& Akingbala 2015; Coleman et al. 2013; Duta \& Culetu, 2015; Mancebo et al. 2015; Rai et al., 2014; Songré-Ouattara et al. 2016; Torbica et al. 2012) (Table 1). Because of the lack of gluten, these products could be well tolerated in celiac disease patients as part of a gluten-free diet.

\section{Use of improved biscuits in clinical trials}

The objective of the use of improved biscuits in clinical trials is both to investigate the contribution of improved biscuits to the recommended nutrients intake of young children and the influence of the food matrix on the bioavailability of biscuit nutrients during digestion (Table 4) (Austria et al. 2016; Bowen et al. 2019; Buffière et al. 2020; $\mathrm{Hu}$ et al. 2013; Jenkins et al. 2008; Kriengsinyos et al. 2015).

Food that is rich in dietary fiber has been suggested to contribute to body weight loss, and lower triacylglycerol levels. Several studies have investigated the effect of supplemented biscuit with high fiber product on body weight, body composition, and blood lipids in overweight and obese subjects (Hassanzadeh-Rostami et al. 2020; Hu et al. 2013; Kuang et al. 2020). For example, the consumption of biscuits supplemented with soy fiber 
by overweight and obese college adults at breakfast for 12 weeks (approximately $100 \mathrm{~g} /$ day) has led to a loss of body weight, body mass index, and serum LDLcholesterol concentrations compared to a control group, which received not supplemented biscuits ( $\mathrm{Hu}$ et al., 2013). Kuang et al. (2020) have observed similar results with biscuits supplemented with flaxseed meal (Kuang et al. 2020).

The consumption of fortified biscuit with whey protein and wheat bran by overweight or obese people in a randomized controlled clinical trial during 8 weeks resulted in a loss of appetite, energy intake, and body weight, contrary to the overweight or obese who consumed not fortified biscuits (Hassanzadeh-Rostami et al. 2020).

Fortification of food with micronutrient is a strategy used in food programs to overcome micronutrient deficiency. Thus, biscuits are mostly used in clinical trials as vehicles for micronutrients, with the purpose to improve micronutrient status (Bouhouch et al. 2016; Nga et al. 2009). This food-based strategy is well-known to decrease the risk of anemia and deficiencies of micronutrients such as zinc and iodine. Bouhouch et al. (2016), when using the biscuit as a food vehicle fortified with ferrous sulfate (FeSO 4) and ferric sodium EDTA (NaFeEDTA) in a randomized controlled trial, showed an improved iron status of children (Bouhouch et al. 2016). Nga et al. (2009) obtained a decrease in the risk of anemia and deficiencies of zinc and iodine by $40 \%$ (Nga et al. 2009).

The consumption of multi-micronutrient fortified biscuits showed significant improvement in cognitive test results (Nga et al. 2009). Soy dietary protein used in the supplementation of biscuit showed greater improvement in nonverbal cognitive (fluid intelligence) performance compared with peers who received isocaloric beef or wheat biscuits (Loo et al. 2017).

The daily supplementation of pregnant women's diet with high energy groundnut biscuits $(4.3 \mathrm{MJ} /$ day) during 20 weeks significantly increases the weight gain in pregnancy and the birth weight (Ceesay et al. 1997).

Ginger has been used in the production of biscuit for its good effect against nausea and vomiting during pregnancy. Thus, Basirat et al. (2009), when using ginger biscuits their clinical trial, showed that these food products have a positive effect on the remission of nausea during pregnancy (Basirat et al. 2009).

It has been reported that the consumption of multimicronutrient fortified biscuits reduces the prevalence of parasitic infections compared to children who received unfortified biscuits (Nga et al. 2009, 2011).

The consumption of biscuits enriched with olive pomace led to a significant increase in the metabolic output of the gut microbiota (Conterno et al. 2019).
Autism spectrum disorder affects multiple systems of the body. It is the case for metabolic, gastrointestinal, immunological, mitochondrial, and neurological systems. Ghalichi et al. (2016) used a gluten-free diet (gluten-free pasta and biscuits and gluten-free breads) in a randomized clinical trial to determine their effect on gastrointestinal symptoms and autism spectrum disorders. They concluded that these gluten-free biscuits might be effective product to manage of the gastrointestinal symptoms and autism spectrum disorders behaviors (Ghalichi et al. 2016).

The studies of Clifton and Keogh concluded that wheat wholegrain biscuits have a lowering effect on cholesterol rate in the blood (Clifton \& Keogh 2018). This is an advantage because the use of wheat wholegrain biscuit at breakfast is a convenient, easy and nutritious way to achieve $2 \mathrm{~g}$ /day of plant sterol intake, and its form lends itself to excellent daily compliance (Clifton \& Keogh 2018).

\section{Conclusion}

This review emphasizes the scientific information about the nutritional attributes of biscuits and their correlation with human health. The biscuit industry intends to improve human health through the development of a wide variety of biscuits in the form of food high in essential and/or functional nutrient. Biscuit products appear to be an excellent food vehicle matrix for the inclusion of a variety of innovative and healthy ingredients and offer various positive functional attributes. The physical, chemical, functional, and rheological properties of these products are significantly influenced by the raw material used and the production process. The functionality of biscuits is the combined result of their physical, chemical, functional, and rheological properties. The different treatments of biscuits leading to the improvement of the nutritional contents have been mainly evidenced as an increase in protein, fiber, and bioactive compounds and a decrease in the hydrolysis index, fat and sugar content. There are many future possibilities for the biscuits industries to develop a wider range of tailor-made functional food products. It is difficult to explain the correlation between biscuits consumption and disease prevention because this aspect is not completely understood. The clinical study is an important step towards improving the understanding of the influence of biscuits on human health. This aspect is not fully understood. The use of biscuits in clinical trials has shown good prospects in improving the diet by providing bioactive compounds such as essential fatty acids, proteins, dietary fibers, soluble polysaccharides, phenolic compounds, vitamins (A, C, F and E), and minerals ( $\mathrm{P}, \mathrm{Mg}, \mathrm{K}, \mathrm{Na}, \mathrm{Fe}$, $\mathrm{Cu}, \mathrm{Mn}$ and $\mathrm{Zn}$ ). However, it is noteworthy that these values need to be tested in vivo to confirm the 
physiological benefits on human health of biscuits consumption. Several clinical trials have been conducted with biscuits. But, further clinical trials with more participants and over a longer duration could provide a better understanding of the health benefits of improved biscuits. Also, the clinical trials are minimal compared to the numbers of improved biscuits that have been developed.

\section{Acknowledgements}

Not applicable.

\section{Authors' contributions}

MG, LTS-O and AS conceived and designed the paper; MG, and FB collected and analysed literatures and wrote the paper; LTS-O, HS-L, YT, and AS reviewed and edited the manuscript. The authors read and approved the final manuscript

\section{Funding}

The authors declare that no funding was provided for the present work.

\section{Availability of data and materials}

Data and materials used include all the original reviewed articles which are available.

\section{Declarations}

Ethics approval and consent to participate

Not applicable.

\section{Consent for publication}

Not applicable.

\section{Competing interests}

The authors declare no conflict of interest.

\section{Received: 12 July 2021 Accepted: 22 August 2021}

Published online: 01 October 2021

\section{References}

Abou-Zaid, A. A. M., \& Elbandy, M. A. S. (2014). Production and quality evaluation of nutritious high quality biscuits and potato puree tablets supplemented with crayfish Procombarus clarkia protein products. Journal of Applied Sciences Research, 10(7), 43-53.

Adeola, A. A., \& Ohizua, E. R. (2018). Physical, chemical, and sensory properties of biscuits prepared from flour blends of unripe cooking banana, pigeon pea, and sweet potato. Food Science and Nutrition, 6(3), 532-540. https://doi.org/1 $0.1002 / f s n 3.590$.

Adeyeye, S. A., \& Akingbala, J. O. (2015). Physico-chemical and functional properties of cookies produced from sweet potato-maize flour blends. Food Science and Quality Management, 43, 48-57.

Adeyeye, S. A. O. (2020). Quality evaluation and acceptability of cookies produced from rice (Oryza glaberrima) and soybeans (Glycine max) flour blends. Journal of Culinary Science and Technology, 18(1), 54-66. https://doi.org/10.1080/1542 8052.2018.1502113.

Agama-Acevedo, E., Islas-Hernandez, J. J., Pacheco-Vargas, G., Osorio-Diaz, P., \& Bello-Perez, L. A. (2012). Starch digestibility and glycemic index of cookies partially substituted with unripe banana flour. LWT - Food Food Science and Technology., 46(1), 177-182. https://doi.org/10.1016/j.Iwt.2011.10.010.

Aggarwal, D., Sabikhi, L., \& Kumar, M. H. S. (2016). Formulation of reduced-calorie biscuits using artificial sweeteners and fat replacer with dairy-multigrain approach. NFS Journal, 2, 1-7. https://doi.org/10.1016/.jnfs.2015.10.001.

Ajila, C. M., Leelavathi, K., \& Rao, U. J. S. P. (2008). Improvement of dietary fiber content and antioxidant properties in soft dough biscuits with the incorporation of mango peel powder. Journal of Cereal Science, 48(2), 319326. https://doi.org/10.1016/j.jcs.2007.10.001.

Akoja, S. S., \& Coker, O. J. (2018). Physicochemical, functional, pasting and sensory properties of wheat flour biscuit incorporated with okra powder. International Journal of Food Science and Nutrition, 3(5), 64-70.
Akujobi, I. C. (2018). Nutrient composition and sensory evaluation of cookies produced from cocoyam (Xanthosoma sagittifolium) and tiger nut (Cyperus esculentus) flour blends. International Journal of Innovative Food, Nutrition and Sustainable Agriculture, 6(3), 33-39.

Apeda agri exchange (2020) exchange.apeda.gov.in.

Arun, K. B., Persia, F., Aswathy, P. S., Chandran, J., Sajeev, J., \& P., \& Nisha, P. (2015). Plantain peel - a potential source of antioxidant dietary fibre for developing functional cookies. Journal of Food Science and Technology, 52(10), 63556364. https://doi.org/10.1007/s13197-015-1727-1.

Austria, J. A., Aliani, M., Malcolmson, L. J., Dibrov, E., Blackwood, D. P., Maddaford, T. G., ... Pierce, G. N. (2016). Daily choices of functional foods supplemented with milled flaxseed by a patient population over one year. Journal of Functional Foods, 26, 772-780. https://doi.org/10.1016/j.jff.2016.08.045.

Ayo, J. A., Ojo, M. O., Omelagu, C. A., \& Kaaer, R. U. (2018). Quality characterization of Acha-mushroom blend flour and biscuit. Nutrition and Food Science International Journal, 7(3), 1-10. https://doi.org/10.19080/ NFSIJ.2018.07.555715.

Banerjee, C., Singh, R., Jha, A., \& Mitra, J. (2014). Effect of inulin on textural and sensory characteristics of sorghum based high fibre biscuits using response surface methodology. Journal of Food Science and Technology, 51(10), 27622768. https://doi.org/10.1007/s13197-012-0810-0.

Basirat, Z., Moghadamnia, A., Kashifard, M., \& Sharifi-Razavi, A. (2009). The effect of ginger biscuit on nausea and vomiting in early pregnancy. Acta Medica Iranica, 47(1), 51-56.

Benkadri, S., Salvador, A., Zidoune, M. N., \& Sanz, T. (2018). Gluten-free biscuits based on composite rice-chickpea flour and xanthan gum. Food Science and Technology International, 1-10. https://doi.org/10.1177/1082013218779323.

Biao, Y., Chen, X., Wang, S., Chen, G., Mcclements, D. J., \& Zhao, L. (2020). Impact of mushroom (Pleurotus eryngii) flour upon quality attributes of wheat dough and functional cookies-baked products. Food Science and Nutrition, 8(1), 361370. https://doi.org/10.1002/fsn3.1315.

Biguzzi, C., Schlich, P., \& Lange, C. (2014). The impact of sugar and fat reduction on perception and liking of biscuits. Food Quality and Preference, 35, 41-47. https://doi.org/10.1016/j.foodqual.2014.02.001.

Błońska, A., Marzec, A., \& Błaszczyk, A. (2014). Instrumental evaluation of acoustic and mechanical texture properties of short-dough biscuits with different content of fat and inulin. Journal of Texture Studies, 45(3), 226-234. https:// doi.org/10.1111/jtxs.12068.

Bouhouch, R. R., El-Fadeli, S., Andersson, M., Aboussad, A., Chabaa, L., Zeder, C., ... Zimmermann, M. B. (2016). Effects of wheat-flour biscuits fortified with iron and EDTA, alone and in combination, on blood lead concentration, iron status, and cognition in children: A double-blind randomized controlled trial. American Journal of Clinical Nutrition, 104(5), 1318-1326. https:/doi.org/10.3945/ajcn/115.129346.

Bowen, J., Luscombe-Marsh, N. D., Stonehouse, W., Tran, C., Rogers, G. B., Johnson, N., ... Brinkworth, G. D. (2019). Effects of almond consumption on metabolic function and liver fat in overweight and obese adults with elevated fasting blood glucose: A randomised controlled trial. Clinical Nutrition ESPEN, 30, 10-18. https://doi.org/10.1016/j.cInesp.2018.12.088.

Buffière, C., Hiolle, M., Peyron, M.-A., Richard, R., Meunier, N., Batisse, C., ... SavaryAuzeloux, I. (2020). Food matrix structure (from biscuit to custard) has an impact on folate bioavailability in healthy volunteers. European Journal of Nutrition., 60(1), 411-423. https://doi.org/10.1007/s00394-020-02258-5.

Canalis, M. S. B., Leon, A. E., \& Ribotta, P. D. (2017). Effect of inulin on dough and biscuit quality produced from different flours. International Journal of Food Studies, 6(1), 13-23. https://doi.org/10.7455/ijfs/6.1.2017.a2.

Cauvain, S. P., \& Young, L. S. (2008). The nature of baked product structure. In S P. Cauvain, \& L. S. Young (Eds.), Baked products: Science, technology and practice, (pp. 99-118). Oxford, UK: Blackwell publishing.

Ceesay, S. M., Prentice, A. M., Cole, T. J., Foord, F., Weaver, L. T., Poskitt, E. M. E., \& Whitehead, R. G. (1997). Effects on birth weight and perinatal mortality of maternal dietary supplements in rural Gambia: 5 year randomised controlled trial. British Medical Journal, 315(7111), 786-790. https://doi.org/10.1136/ bmj.315.7111.786.

Chavan, J. K., Kadam, S. S., \& Reddy, N. R. (1993). Nutritional enrichment of bakery products by supplementation with nonwheat flours. Critical Reviews in Food Science and Nutrition, 33(3), 189-226. https://doi.org/10.1080/10408399309527620.

Chavan, R. S., Sandeep, K., Basu, S., \& Bhatt, S. (2016). Biscuits, cookies, and crackers: Chemistry and manufacture. Encyclopedia of Food and Health, 437444. https://doi.org/10.1016/B978-0-12-384947-2.00076-3.

Chinma, C. E., James, S., Imam, H., Ocheme, O. B., Anuonye, J. C., \& Yakubu, C. M. (2011). Physicochemical and sensory properties and in-vitro digestibility of 
biscuits made from blends of tigernut (Cyperus esculentus) and pigeon pea (Cajanus cajan). Nigerian Journal of Nutritional Sciences, 32(1), 55-62. https:// doi.org/10.4314/njns.v32i1.67816.

Chugh, B., Singh, G., \& Kumbhar, B. K. (2013). Development of low-fat soft dough biscuits using carbohydrate-based fat replacers. International Journal of Food Science, 576153, 1-12. https://doi.org/10.1155/2013/576153.

Chung, H.-J., Cho, A., \& Lim, S.-T. (2014). Utilization of germinated and heatmoisture treated brown Rices in sugar-snap cookies. LWT - Food Sciences and Technology., 57(1), 260-266. https://doi.org/10.1016/j.lwt.2014.01.018.

Clifton, P., \& Keogh, J. (2018). Cholesterol-lowering effects of plant sterols in one serve of wholegrain wheat breakfast cereal biscuits-a randomised crossover clinical trial. Foods, 7(39), 1-7. https://doi.org/10.3390/foods7030039.

CODEX CAC/GL 08. (1991). Codex Alimentarius: Guidelines on formulated supplementary foods for older infants and Young children. Vol. 4. FAO/WHO Joint Publications. http://www.fao.org/fao-who-codexalimentarius/codextexts/list-standards

Coleman, J., Abaye, A. O., Barbeau, W., \& Thomason, W. (2013). The suitability of teff flour in bread, layer cakes, cookies and biscuits. International Journal of Food Sciences and Nutrition, 64(7), 877-881. https://doi.org/10.3109/096374 86.2013 .800845

Colla, K., Costanzo, A., \& Gamlath, S. (2018). Fat replacers in baked food products. Foods, 7(192), 1-12. https://doi.org/10.3390/foods7120192.

Conterno, L., Martinelli, F., Tamburini, M., Fava, F., Mancini, A., Sordo, M., ... Tuohy, K. (2019). Measuring the impact of olive pomace enriched biscuits on the gut microbiota and its metabolic activity in mildly hypercholesterolaemic subjects. European Journal of Nutrition, 58(1), 63-81. https://doi.org/10.1007/ s00394-017-1572-2.

Costa, A. C. S., Pereira, D. E., Veríssimo, C. M., Bomfim, M. A., Queiroga, R. C., Madruga, M. S., ... Soares, J. K. (2019). Developing cookies formulated with goat cream enriched with conjugated linoleic acid. PLoS One, 14(9), e0212534. https://doi.org/10.1371/journal.pone.0212534

Coutinho de Moura, C., Peter, N., de Oliveira Schumacker, B., Borges, L. R., \& Helbig, E. (2014). Biscuits enriched with brown flaxseed (Linum usitatissiumun L.): Nutritional value and acceptability. Demetra, 9(1), 71-81. https://doi.org/1 0.12957/demetra.2014.6899.

Davidson, I. (2019). Biscuit, cookie and cracker production: Process, production and packaging equipment, (2nd ed., ). London: Elsevier Inc.

De la Barca, A. M. C., Rojas-Martínez, M. E., Islas-Rubio, A. R., \& Cabrera-Chavez, F. (2010). Gluten-free breads and cookies of raw and popped amaranth flours with attractive technological and nutritional qualities. Plant Foods for Human Nutrition, 65(3), 241-246. https://doi.org/10.1007/s11130-010-0187-z.

Delcour, J. A., \& Hoseney, R. C. (2010). Principles of cereal science and technology, (3rd ed., ). USA: AACC International. https://doi.org/10.1094/9781891127632.

Denis, A. (2011). Les biscuits et gâteaux : toute une diversité. Cahiers de nutrition et de diététique, 46(2), 86-94. https://doi.org/10.1016/j.cnd.2010.11.002.

Dhankhar, J., Vashistha, N., \& Sharma, A. (2019). Development of biscuits by partial substitution of refined wheat flour with chickpea flour and date powder. Journal of Microbiology, Biotechnology and Food Sciences, 8(4), 1093-1097. https://doi.org/10.15414/jmbfs.2019.8.4.1093-1097.

Duta, D. E., \& Culetu, A. (2015). Evaluation of rheological, physicochemical, thermal, mechanical and sensory properties of oat-based gluten free cookies. Journal of Food Engineering, 162, 1-8. https://doi.org/10.1016/j.jfoodeng.2015. 04.002 .

Duta, D. E., Culetu, A., Mohan, G. (2019). Sensory and physicochemical changes in gluten-free oat biscuits stored under different packaging and light conditions. Journal of Food Science and Technology, 56(8), 3823-3835. https://doi.org/10.1007/s13197-019-03853-z

Erinc, H., Behic, M., \& Tekin, A. (2018). Different sized wheat bran fibers as fat mimetic in biscuits: Its effects on dough rheology and biscuit quality. Journal of Food Science and Technology, 55(10), 3960-3970. https://doi.org/10.1007/ s13197-018-3321-9.

Ferreira, M. S. L., Santos, M. C. P., Moro, T. M. A., Basto, G. J., Andrade, R. M. S., \& Gonçalves, É. C. B. A. (2013). Formulation and characterization of functional foods based on fruit and vegetable residue flour. Journal of Food Science and Technology, 52(2), 822-830. https://doi.org/10.1007/s13197-013-1061-4

Filipčev, B., Šimurina, O., \& Bodroža-Solarov, M. (2014). Quality of gingernut type biscuits as affected by varying fat content and partial replacement of honey with molasses. Journal of Food Science and Technology, 51(11), 3163-3171. https://doi.org/10.1007/s13197-012-0805-x.

Filipčev, B., Šimurina, O., Hadnađev, T. D., Jevtić-Mučibabić, R., Filipović, V., \& Lončar, B. (2015). Effect of liquid (native) and dry molasses originating from sugar beet on physical and textural properties of gluten-free biscuit and biscuit dough: Gluten-free biscuits enriched with beet molasses. Journal of Texture Studies, 46(5), 353-364. https://doi.org/10.1111/jtxs.12135.

Forker, A., Zahn, S., \& Rohm, H. (2012). A combination of fat replacers enables the production of fat-reduced shortdough biscuits with high-sensory quality. Food and Bioprocess Technology, 5(6), 2497-2505. https://doi.org/10.1007/s11 947-011-0536-4.

French Ministry of Health (2006). Second National Nutrition and health Programme 2006-2010. Paris: French Ministry of Health.

Galanakis, C. M. (2020). The food systems in the era of the coronavirus (COVID-19) pandemic crisis. Foods, 9(4), 523. https://doi.org/10.3390/foods9040523.

Gallagher, E., O'Brien, C. M., Scannell, A. G. M., \& Arendt, E. K. (2003). Evaluation of sugar replacers in short dough biscuit production. Journal of Food Engineering, 56(2), 261-263. https://doi.org/10.1016/S0260-8774(02)00267-4.

Ghalichi, F., Ghaemmaghami, J., Malek, A., \& Ostadrahimi, A. (2016). Effect of gluten free diet on gastrointestinal and behavioral indices for children with autism spectrum disorders: A randomized clinical trial. World Journal of Pediatrics, 12(4), 436-442. https://doi.org/10.1007/s12519-016-0040-z.

Ghoshal, G., \& Kaushik, P. (2020). Development of soymeal fortified cookies to combat malnutrition. Legume science e43:1-13. https://doi.org/10.1002/leg3.43.

Góngora Salazar, V. A., Vázquez Encalada, S., Corona Cruz, A., \& Segura Campos, M. R. (2018). Stevia rebaudiana : A sweetener and potential bioactive ingredient in the development of functional cookies. Journal of Functional Foods, 44, 183-190. https://doi.org/10.1016/j.jff.2018.03.007.

Granato, D., Branco, G. F., Nazzaro, F., Cruz, A. G., \& Faria, J. A. F. (2010). Functional foods and nondairy probiotic food development: Trends, concepts, and products. Comprehensive Reviews in Food Science and Food Safety, 9(3), 292302. https://doi.org/10.1111/j.1541-4337.2010.00110.x.

Hadnađev, T. R. D., Torbica, A. M., \& Hadnađev, M. S. (2013). Influence of buckwheat flour and carboxymethyl cellulose on rheological behaviour and baking performance of gluten-free cookie dough. Food Bioprocess Technology, 6(7), 1770-1781. https://doi.org/10.1007/s11947-012-0841-6.

Han, J., Janz, J. A. M., \& Gerlat, M. (2010). Development of gluten-free cracker snacks using pulse flours and fractions. Food Research International, 43(2), 627-633. https://doi.org/10.1016/j.foodres.2009.07.015.

Hassan, A. A., Rasmy, N. M., Foda, M. I., \& Bahgaat, W. K. (2012). Production of functional biscuits for lowering blood lipids. World Journal of Dairy \& Food Sciences, 7(1), 01-20. https://doi.org/10.5829/idosi.wjdfs.2012.7.1.1101.

Hassanzadeh-Rostami, Z., Abbasi, A., \& Faghih, S. (2020). Effects of biscuit fortified with whey protein isolate and wheat bran on weight loss, energy intake, appetite score, and appetite regulating hormones among overweight or obese adults. Journal of Functional Foods, 70(103743), 1-10. https://doi.org/1 0.1016/j.jff.2019.103743.

Hercberg, S., Chat-Yung, S., \& Chauliac, M. (2008). The French national nutrition and health program: 2001-2006-2010. International Journal of Public Health 53(2), 68-77. https://doi.org/10.1007/s00038-008-7016-2.

Hooda, S., \& Jood, S. (2005). Organoleptic and nutritional evaluation of wheat biscuits supplemented with untreated and treated fenugreek flour. Food Chemistry, 90(3), 427-435. https://doi.org/10.1016/j.foodchem.2004.05.006.

Hu, X., Gao, J., Zhang, Q., Fu, Y., Zhu, K., Li, S., \& Li, D. (2013). Soy fiber improves weight loss and lipid profile in overweight and obese adults: A randomized controlled trial. Molecular Nutrition and Food Research., 57(12), 2147-2154. https://doi.org/10.1002/mnfr.201300159.

Ibrahim, S. M. (2009). Evaluation of production and quality of salt-biscuits supplemented with fish protein concentrate. World Journal of Dairy and Food Sciences, 4(1), 28-31.

Jang, A., Bae, W., Hwang, H. S., Lee, H. G., \& Lee, S. (2015). Evaluation of canola oil oleogels with candelilla wax as an alternative to shortening in baked goods. Food Chemestry, 187, 525-529. https://doi.org/10.1016/j.foodchem.2015.04.110.

Jenkins, A. L., Jenkins, D. J. A., Wolever, T. M. S., Rogovik, A. L., Jovanovski, E., Božikov, V., ... Vuksan, V. (2008). Comparable postprandial glucose reductions with viscous fiber blend enriched biscuits in healthy subjects and patients with diabetes mellitus: Acute randomized controlled clinical trial. Croatian Medical Journal, 49(6), 722-782. https://doi.org/10.3325/cmj.2008.49.722.

Jung, E. K., \& Joo, N. M. (2010). Optimization of iced cookie prepared with dried oak mushroom (Lentinus edodes) powder using response surface methodology. Korean Society of Food and Cookery Science, 26(2), 121-128.

Jung, H., Chen, C.-Y. O., Blumberg, J. B., \& Kwak, H-K (2018). The effect of almonds on vitamin $\mathrm{E}$ status and cardiovascular risk factors in Korean adults: a randomized clinical trial. European Journal of Nutrition, 57(18), 2069-2079. https://doi.org/10.1007/s00394-017-1480-5 
Kadam, S. U., \& Prabhasankar, P. (2010). Marine foods as functional ingredients in bakery and pasta products. Food Research International, 43(8), 1975-1980. https://doi.org/10.1016/j.foodres.2010.06.007.

Karnopp, A. R., Figueroa, A. M., Los, P. R., Teles, J. C., Simões, D. R. S., Barana, A. C., ... Granato, D. (2015). Effects of whole-wheat flour and Bordeaux grape pomace (Vitis labrusca L.) on the sensory, physicochemical and functional properties of cookies. Food Science and Technology, 35(4), 750-756. https:// doi.org/10.1590/1678-457X.0010.

Kaur, M., Sandhu, K. S., Arora, A., \& Sharma, A. (2015). Gluten free biscuits prepared from buckwheat flour by incorporation of various gums: Physicochemical and sensory properties. LWT - Food Science and Technology, 62(1), 628-632. https://doi.org/10.1016/j.lwt.2014.02.039.

Kekalih, A., Sagung, I. O. A. A., Fahmida, U., Ermayani, E., \& Mansyur, M. (2019). A multicentre randomized controlled trial of food supplement intervention for wasting children in Indonesia-study protocol. BMC Public Health, 19(305). https://doi.org/10.1186/s12889-019-6608-5.

Kohajdova, Z., Karovicova, J., \& Jurasova, M. (2013). Influence of grape-fruit dietary fibre rich powder on the rheological characteristics of wheat flour dough and on biscuit quality. Acta Alimentaria, 42(1), 91-101. https://doi.org/10.1 556/AAlim.42.2013.1.9

Kohajdova, Z., Karovicova, J., Jurasova, M., \& Kukurova, K. (2011). Application of citrus dietary fibre preparations in biscuit production. Journal of Food and Nutrition Research., 50(3), 182-190.

Kriengsinyos, W., Wangtong, A., \& Komindr, S. (2015). Serum cholesterol reduction efficacy of biscuits with added plant stanol ester. Cholesterol, 353164, 1-9. https://doi.org/10.1155/2015/353164

Krystyjan, M., Gumul, D., Ziobro, R., \& Sikora, M. (2015). The effect of inulin as a fat replacement on dough and biscuit properties. Journal of Food Quality, 38(5), 305-315. https://doi.org/10.1111/jfk.12148.

Kuang, X., Kong, Y., Hu, X., Li, K., Guo, X., Liu, C., ... Li, D. (2020). Defatted flaxseed flour improves weight loss and lipid profile in overweight and obese adults: A randomized controlled trial. Food \& Function, 9(11), 8237-8247. https://doi. org/10.1039/D0FO00838A.

Kuchtová, V., Karovičová, J., Kohajdová, Z., Minarovičová, L., \& Kimličková, V. (2016). Effects of white grape preparation on sensory quality of cookies. Acta Chimica Slovaca, 9(2), 84-88. https://doi.org/10.1515/acs-2016-0014.

Kuchtová, V., Kohajdová, Z., Karovičová, J., \& Lauková, M. (2018). Physical, textural and sensory properties of cookies incorporated with grape skin and seed preparations. Polish Journal of Food and Nutrition Sciences, 68(4), 309-317. https://doi.org/10.2478/pjfns-2018-0004.

Lee, N.-Y., \& Kang, C.-S. (2018). Quality improvement and antioxidant activity of sugar-snap cookies prepared using blends of cereal flour. Preventive Nutrition and Food Science, 23(2), 160-165. https://doi.org/10.3746/pnf.2018.23.2.160.

Lee, Y.-T., \& Puligundla, P. (2016). Characteristics of reduced-fat muffins and cookies with native and modified rice starches. Emirates Journal Food and Agriculture 28(5), 311-316. https://doi.org/10.9755/ejfa.2015-05-227.

Lin, S. D., Lee, C. C., Mau, J. L., Lin, L. Y., \& Chiou, S. Y. (2010). Effect of erythritol on quality characteristics of reduced calorie Danish cookies. Journal of Food Quality, 33(s1), 14-26. https://doi.org/10.1111/j.1745-4557.2010.00307.x.

Loo, K. K., Rizzo, S., Chen, Q., Weiss, R. E., Sugar, C. A., Ettyang, G., ... Neumann, C. G. (2017). Effects of biscuit-type feeding supplementation on the neurocognitive outcomes of HIV-affected school-age children: A randomized, double-blind, controlled intervention trial in Kenya. Family Medicine and Community Health, 5(4), 245-258. https://doi.org/10.15212/FMCH.2017.0130.

Mancebo, C. M., Picon, J., \& Gomez, M. (2015). Effect of flour properties on the quality characteristics of gluten free sugar-snap cookies. Food Science and Technology, 66(1), 264-269. https://doi.org/10.1016/j.lwt.2015.05.057.

Manley, D. (2011). Manley's technology of biscuits, crackers and cookies, (4e ed. , ). Oxford: Elsevier, Woodhead Publishing. https://doi.org/10.1533/ 9780857093646.

Martin-Diana, N. I., Albertos, I., Sanchez, M. S., Herrero, A., Sanz, M. A., \& Rico, D. (2016). Valorization of carob's germ and seed peel as natural antioxidant ingredients in gluten-free crackers: Carob antioxidant by-products in glutenfree snack. Journal of Food Processing and Preservation, 41(2), e12770. https:// doi.org/10.1111/jfpp.12770 .

Mir, S. A., Bosco, S. J. D., Shah, M. A., Santhalakshmy, S., \& Mir, M. M. (2015). Effect of apple pomace on quality characteristics of brown rice based cracker. Journal of the Saudi Society of Agricultural Sciences, 16(1), 25-32. https://doi. org/10.1016/j.jssas.2015.01.001.

Naknaen, P., Itthisoponkul, T., Sondee, A., \& Angsombat, N. (2016). Utilization of watermelon rind waste as a potential source of dietary fiber to improve health promoting properties and reduce glycemic index for cookie making. Food Science and Biotechnology, 25(2), 415-424. https://doi.org/10.1007/s10068-016-0057-z.

Nga, T. T., Winichagoon, P., Dijkhuizen, M. A., Khan, N. C., Wasantwisut, E., Furr, H., \& Wieringa, F. T. (2009). Multi-micronutrient-fortified biscuits decreased prevalence of anemia and improved micronutrient status and effectiveness of deworming in rural Vietnamese school children. The Journal of Nutrition, 139(5), 1013-1021. https://doi.org/10.3945/jn.108.099754.

Nga, T. T., Winichagoon, P., Dijkhuizen, M. A., Khan, N. C., Wasantwisut, E., \& Wieringa, F. T. (2011). Decreased parasite load and improved cognitive outcomes caused by deworming and consumption of multi-micronutrient fortified biscuits in rural Vietnamese schoolchildren. American Journal of Tropical Medicine and Hygiene, 85(2), 333-340. https://doi.org/10.4269/ajtmh.2011.10-0651.

Nogueira, A. D. C., \& Steel, C. J. (2018). Protein enrichment of biscuits: A review. Food Reviews International, 34(8), 796-809. https://doi.org/10.1080/87559129.2 018.1441299.

Okpala, L. C., \& Okoli, E. C. (2011). Nutritional evaluation of cookies produced from pigeon pea, cocoyam and sorghum flour blends. African Journal of Biotechnology, 10(3), 433-438. https://doi.org/10.5897/AJB10.1318.

Okumura, T., Ohuchida, K., Sada, M., Abe, T., Endo, S., Koikawa, K. ... Nakamura, M. (2017). Extra-pancreatic invasion induces lipolytic and fibrotic changes in the adipose microenvironment, with released fatty acids enhancing the invasiveness of pancreatic cancer cells. Oncotarget, 8(11), 18280-18295. https://doi.org/10.18632/oncotarget.15430.

Omran, A. A., Ibrahim, O. S., \& Mohamed, Z. E.-O. M. (2016). Quality characteristics of biscuit prepared from wheat and flaxseed flour. Advances in Food Sciences, 38(4), 129-138.

Onabanjo, O. O., \& Ighere, D. A. (2014). Nutritional, functional and sensory properties of biscuit produced from wheat-sweet potato composite. Journal of Food Technology Research, 1(2), 111-121. https://doi.org/10.18488/journal. 58/2014.1.2/58.2.111.121.

Onacik-Gür, S., Zbikowska, A., \& Jaroszewska, A. (2015). Effect of high-oleic sunflower oil and other pro-health ingredients on physical and sensory properties of biscuits. CyTA - Journal of Food, 13(4), 621-628. https://doi.org/1 0.1080/19476337.2015.1032358.

Ovando-Martinez, M., Sáyago-Ayerdi, S., Agama-Acevedo, E. E., Goñi, I. A., \& BelloPérez, L. A. (2009). Unripe banana flour as an ingredient to increase the undigestible carbohydrates of pasta. Food Chemistry, 113(1), 121-126. https:// doi.org/10.1016/j.foodchem.2008.07.035.

Pareyt, B., Goovaerts, M., Broekaert, W. F., \& Delcour, J. A. (2011). Arabinoxylan oligosaccharides (AXOS) as a potential sucrose replacer in sugar-snap cookies. LWT - Food Science and Technology, 44(3), 725-728. https://doi.org/1 0.1016/j.Iwt.2010.11.008

Pareyt, B., Talhaoui, F., Kerckhofs, G., Brijs, K., Goesaert, H., Wevers, M., \& Delcour, J. A. (2009). The role of sugar and fat in sugar-snap cookies: Structural and textural properties. Journal of Food Engineering, 90(3), 400-408. https://doi. org/10.1016/j.jfoodeng.2008.07.010.

Pasqualone, A., Laddomada, B., Boukid, F., De Angelis, D., \& Summo, C. (2020) Use of almond skins to improve nutritional and functional properties of biscuits: An example of upcycling. Foods, 9(1705). https://doi.org/10.3390/ foods9111705.

Perego, P., Sordi, A., Guastalli, R., \& Converti, A. (2007). Effects of changes in ingredient composition on the rheological properties of a biscuit industry dough. International Journal of Food Science and Technology, 42(6), 649-657. https://doi.org/10.1111/j.1365-2621.2006.01330.x.

Pourmohammadi, K., Najafi, M. B. H., Majzoobi, M., Koocheki, A., \& Farahnaki, A. (2017). Evaluation of dough rheology and quality of sugar free biscuits: Isomalt, maltodextrin, and stevia. Carpathian Journal of Food Science and Technology, 9(4), 119-130.

Radočaj, O., Dimić, E., \& Tsao, R. (2014). Effects of hemp (Cannabis sativa L.) seed oil press-cake and decaffeinated green tea leaves (Camellia sinensis) on functional characteristics of gluten-free crackers. Journal of Food Science, 79(3), C318-C325. https://doi.org/10.1111/1750-3841.12370.

Rai, S., Kaur, A., \& Singh, B. (2014). Quality characteristics of gluten free cookies prepared from different flour combinations. Journal of Food Science and Technology, 51(4), 785-789. https://doi.org/10.1007/s13197-011-0547-1.

Rodríguez-García, J., Laguna, L., Puig, A., Salvador, A., \& Hernando, I. (2013). Effect of fat replacement by inulin on textural and structural properties of short dough biscuits. Food Bioprocess Technology, 6(10), 2739-2750. https://doi. org/10.1007/s11947-012-0919-1.

Romanchik-Cerpovicz, J. E., Jeffords, M. J. A., \& Onyenwoke, A. C. (2018). College student acceptance of chocolate bar cookies containing puree of canned 
green peas as a fat-ingredient substitute. Journal of Culinary Science and Technology, 17(6), 1-12. https://doi.org/10.1080/15428052.2078.1492480.

Rosell, C. M., Barro, F., Sousa, C., \& Mena, M. C. (2014). Cereals for developing gluten-free products and analytical tools for gluten detection. Journal of Cereal Science, 59(3), 354-364. https://doi.org/10.1016/j.jcs.2013.10.001.

Sahin, A. W., Rice, T., Zannini, E., Lynch, K. M., Coffey, A., \& Arendt, E. K. (2019). The incorporation of sourdough in sugar-reduced biscuits: A promising strategy to improve techno-functional and sensory properties. European Food Research and Technology, 245(9), 1841-1854. https://doi.org/10.1007/s00217019-03302-3.

Šaponjac, V. T., Ćetković, G., Čanadanović-Brunet, J., Pajin, B., Djilas, S., Petrović, J., ... Vulić, J. (2016). Sour cherry pomace extract encapsulated in whey and soy proteins: Incorporation in cookies. Food Chemestry, 207, 27-33. https://doi. org/10.1016/j.foodchem.2016.03.082

Šarić, B., Mišan, A., Mandić, A., Nedeljković, N., Pojić, M., Pestorić, M., \& Đilas, S. (2016). Valorisation of raspberry and blueberry pomace through the formulation of value-added gluten-free cookies. Journal of Food Science and Technology, 53(2), 1140-1150. https://doi.org/10.1007/s13197-015-2128-1.

Sedej, I., Sakač, M., Mandić, A., Mišan, A., Pestorić, M., Šimurina, O., \& ČanadanovićBrunet, J. (2011). Quality assessment of gluten-free crackers based on buckwheat flour. LWT - Food Science and Technology, 44(3), 694-699. https:// doi.org/10.1016/j.lwt.2010.11.010

Serial, M. R., Blanco Canalis, M. S., Carpinella, M., Valentinuzzi, M. C., León, A. E., Ribotta, P. D., \& Acosta, R. H. (2016). Influence of the incorporation of fibers in biscuit dough on proton mobility characterized by time domain NMR. Food Chemistry, 192, 950-957. https://doi.org/10.1016/j.foodchem.2015.07.101.

Silky, M. P. G., \& Tiwari, A. (2014). Development of high protein biscuits using pigeon pea broken flour. International Journal of Engineering and Innovative Technology, 4(6), 84-89. https://doi.org/10.17605/OSF.IO/7BJ5A.

Singh, A., \& Kumar, P. (2017). Gluten free approach in fat and sugar amended biscuits: A healthy concern for obese and diabetic individuals. Journal of Food Processing and Preservation, 42(e13546), 1-7. https://doi.org/10.1111/ jfpp.13546.

Songré-Ouattara, L. T., Gorga, K., Bationo, F., Savadogo, A., \& Diawara, B. (2016). Utilisation du moringa, de la spiruline, de la patate douce à chair orange et d'un complexe minéral et vitaminique dans la fabrication de biscuits de sorgho enrichis destinés aux jeunes. International Journal of Biological and Chemical Sciences, 10(4), 1651-1665. https://doi.org/10.4314/ijbcs.v10i4.17.

Songré-Ouattara, L. T., Goubgou, M., \& Savadogo, A. (2017). Impact de l'emballage et de la durée de conservation sur la qualité nutritionnelle et microbiologique des biscuits de sorgho enrichis au moringa et à la spiruline. Journal of Applied Biosciences, 109(1), 10561-10570. https://doi.org/10.4314/ja b.v109i1.1.

Srivastava, P., Indrani, D., \& Singh, R. P. (2014). Effect of dried pomegranate (Punica granatum) peel powder (DPPP) on textural, organoleptic and nutritional characteristics of biscuits. International Journal of Food Science and Nutrition, 65(7), 827-833. https://doi.org/10.3109/09637486.2014.937797.

Sudha, M. L., Dharmesh, S. M., Pynam, H., Bhimangouder, S. V., Eipson, S. W., Somasundaram, R., \& Nanjarajurs, S. M. (2016). Antioxidant and cyto/DNA protective properties of apple pomace enriched bakery products. Journal of Food Science and Technology, 53(4), 1909-1918. https://doi.org/10.1007/s131 97-015-2151-2

Sudha, M. L., Vetrimani, R., \& Leelavathi, K. (2007). Influence of fibre from different cereals on the rheological characteristics of wheat flour dough and on biscuit quality. Food Chemistry, 100(4), 1365-1370. https://doi.org/10.1016/j. foodchem.2005.12.013.

Sulieman, A. A., Zhu, K.-X., Peng, W., Hassan, H. A., Obadi, M., Siddeeg, A., \& Zhou, H.-M. (2019). Rheological and quality characteristics of composite gluten-free dough and biscuits supplemented with fermented and unfermented Agaricus bisporus polysaccharide flour. Food Chemistry, 271, 193-203. https:// doi.org/10.1016/j.foodchem.2018.07.189.

Swapna, K. S., \& Jayaraj Rao, K. (2016). Studies on effect of oat and cheese incorporation on sensory and textural quality of short-dough type biscuit. Journal of Food Science and Technology, 53(3), 1505-1514. https://doi.org/10.1 007/s13197-015-2014-x

Tańska, M., Roszkowska, B., Czaplicki, S., Borowska, E. J., Bojarska, J., \& Dabrowska, A. (2016). Effect of fruit pomace addition on shortbread cookies to improve their physical and nutritional values. Plant Foods for Human Nutrition, 71(3), 307-313. https://doi.org/10.1007/s11130-016-0561-6.

Tarancon, P., Fiszman, S. M., Salvador, A., \& Tarrega, A. (2013). Formulating biscuit with healthier fats. Consumer profiling of textural and flavor sensations during consumption. Food Research International, 53(1), 134-140. https://doi. org/10.1016/j.foodres.2013.03.053.

Torbica, A., Hadnađev, M., \& Hadnađev, T. D. (2012). Rice and buckwheat flour characterisation and its relation to cookie quality. Food Research International, 48(1), 277-283. https://doi.org/10.1016/j.foodres.2012.05.001.

Tuohy, K. M., Kolida, S., Lustenberger, A. M., \& Gibson, G. R. (2001). The prebiotic effects of biscuits containing partially hydrolyzed guar gum and fructooligosaccharides - A human volunteer study. British Journal of Nutrition, 86(3), 341-348. https://doi.org/10.1079/bjn2001394.

Turksoy, S., \& Ozkaya, B. (2011). Pumpkin and carrot pomace powders as a source of dietary fiber and their effects on the mixing properties of wheat flour dough and cookie quality. Food Science and Technology Research, 17(6), 545553. https://doi.org/10.3136/fstr.17.545.

van der Smam, R. G. M., \& Renzetti, S. (2019). Understanding functionality of sucrose in biscuits for reformulation purposes. Critical Reviews in Food Science and Nutrition, 59(14), 2225-2239. https://doi.org/10.1080/10408398.201 8.1442315 .

van Stuijvenberg, M. E., Dhansay, M. A., Lombard, C. J., Faber, M. M., \& Benadé, A. J. S. (2001). The effect of a biscuit with red palm oil as a source of b-carotene on the vitamin A status of primary school children: A comparison with $\beta$ carotene from a synthetic source in a randomized controlled trial. European Journal of Clinical Nutrition, 55(8), 657-662. https://doi.org/10.1038/sj.ejcn.1 601196.

Vatankhah, M., Garavand, F., Elhamirad, A., \& Yaghbani, M. (2015). Influence of sugar replacement by stevioside on physicochemical and sensory properties of biscuit. Quality Assurance and Safety of Crops and Foods, 7(3), 393-400. https://doi.org/10.3920/QAS2014.0396.

World Health Organization, nutrition (World Health Organization), 2021, https:// www.who.int/newsroom/fact-sheets/detail/nutrition.

World Health Organization (WHO) (2015). Guideline: Sugars intake for adults and children. Geneva: WHO.

Xu, J., Zhang, Y., Wang, W., \& Li, Y. (2020). Advanced properties of gluten-free cookies, cakes, and crackers: A review. Trends in Food Science and Technology, 103, 200-213. https://doi.org/10.1016/j.tifs.2020.07.017

Zucco, F., Borsuk, Y., \& Arntfield, S. D. (2011). Physical and nutritional evaluation of wheat cookies supplemented with pulse flours of different particle sizes. LWT - Food Science and Technology, 44(10), 2070-2076. https://doi.org/10.1016/j. Iwt.2011.06007.

\section{Publisher's Note}

Springer Nature remains neutral with regard to jurisdictional claims in published maps and institutional affiliations.

Ready to submit your research? Choose BMC and benefit from:

- fast, convenient online submission

- thorough peer review by experienced researchers in your field

- rapid publication on acceptance

- support for research data, including large and complex data types

- gold Open Access which fosters wider collaboration and increased citations

- maximum visibility for your research: over $100 \mathrm{M}$ website views per year

At BMC, research is always in progress.

Learn more biomedcentral.com/submissions 